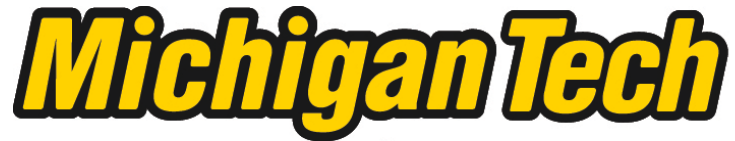 \\ Michigan Technological University Create the Future Digital Commons @ Michigan Tech
}

Dissertations, Master's Theses and Master's Reports - Open

Dissertations, Master's Theses and Master's

Reports

2006

Economic sustainability of the Flambeau Mine Ladysmith, Wisconsin

Anne M. Hartingh

Michigan Technological University

Follow this and additional works at: https://digitalcommons.mtu.edu/etds

Part of the Agricultural and Resource Economics Commons

Copyright 2006 Anne M. Hartingh

\section{Recommended Citation}

Hartingh, Anne M., "Economic sustainability of the Flambeau Mine Ladysmith, Wisconsin", Master's Thesis, Michigan Technological University, 2006.

https://doi.org/10.37099/mtu.dc.etds/445

Follow this and additional works at: https://digitalcommons.mtu.edu/etds

Part of the Agricultural and Resource Economics Commons 


\title{
THE ECONOMIC SUSTAINABILITY OF THE FLAMBEAU MINE LADYSMITH, WISCONSIN
}

\author{
By \\ Anne M. Hartingh
}

\begin{abstract}
A THESIS
Submitted in partial fulfillment of the requirements for the degree of MASTER OF SCIENCE IN MINERAL ECONOMICS
\end{abstract}

\section{MICHIGAN TECHNOLOGICAL UNIVERSITY 2006}

Copyright (C) Anne M. Hartingh 2006 
The thesis, "The Economic Sustainability of the Flambeau Mine Ladysmith, Wisconsin," is hereby approved in partial fulfillment of the requirements for the Degree of MASTER OF SCIENCE IN MINERAL ECONOMICS.

Mineral Economics Program

School of Business and Economics

Signatures:

Thesis Advisor

Mark C. Roberts, Ph.D.

Department Chair

Christa L. Walck, Ph.D.

Date 


\begin{abstract}
Today sustainable development is a very pertinent issue. Communities do not want companies, specifically mining companies, to deplete a natural resource and leave. The goal is to minimize the negative impacts of mining and the boom/bust cycles of natural resource extraction.

In this study a three part framework was developed to analyze the sustainability of the Flambeau Mine in Ladysmith, Wisconsin. The first and second part dealt with an in-depth local and regional analysis and whether the community was developing within its own vision. The third part used nine sustainability measures including:

1. Need Present Generation

2. Future Need

3. Acceptable Legacy

4. Full-Cost

5. Contribution to Economic Development

6. Equity

7. Consent

8. Respect for Ecological Limits, Maintenance of Ecological Integrity and Landscape Requirements

9. Offsetting Restoration
\end{abstract}

This study concluded that the Flambeau Mine was sustainable relative to the first two criteria and that it can be considered mostly sustainable relative to the nine criteria. Overall it can be stated that the Flambeau Mine was a beneficial project to the Ladysmith Wisconsin area. Additionally it appeared to decrease the public's negative perception of mining.

Recommendations for future analytical work are made. Suggestions are made as to how mining companies could increase the potential for the attainment of sustainability in projects. It is recommended that this framework be used by other industries. 


\section{ACKNOWLEDGMENTS}

I would like to first thank my adviser Dr. Mark Roberts for all his help with this project. Also I want to thank the other members of my committee Dr. Gary Campbell, Dr. James Gale and Duane Thayer for their time and suggestions. There are two people from Kennecott Minerals who helped me a great deal with this project. They are Jana Murphy who provided information and was always there to answer my questions and Jon Cherry who helped suggest this topic in the first place. I also want to thank Joan Goodbody a reference librarian at Tech's J.R. Van Pelt Library and Cathy Greer and Stephanie Reed who are both in charge of Inter-Library Loan Services. Finally I would like to thank my family and friends for their help and encouragement throughout my entire graduate school career. 


\section{$\underline{\text { Table of Contents }}$}

Chapter 1

Introduction

Chapter 2

Literature Review

Sustainable Development

Chapter 3

Geology

History of Mining in Wisconsin 16

History of the Flambeau Mine 19

Chapter 4

Analysis

Chapter 5

Comparisons

Chapter 6

Conclusions

60

Recommendations

62

References

64

Appendix A: Local Agreement and Land Use Permit

72

Appendix B: Individual and Business Surveys 


\section{CHAPTER 1}

\section{$\underline{\text { Introduction }}$}

Today the mining industry is seriously considering and applying the concept of sustainable development. Sustainable development is defined on the website dictionary.com as "any construction that can be maintained over time without damaging the environment; development balancing near-term interests with the protection of the interests of future generations." Breaking New Ground: Mining, Minerals, and Sustainable Development, the report of the Mining, Minerals, and Sustainable Development (MMSD) Project states that "The most widely accepted definition of sustainable development is the one used in 1987 by the World Commission on Environment and Development (known as the Brundtland Commission): Sustainable development is development that meets the needs of the present without compromising the ability of future generations to meet their own needs" (MMSD, 2002, p.21).

Historically, in most instances the general public and some companies viewed sustainable development as pertaining only to the environment. This interpretation would mean that a company could not leave a mine site without "clean-up" and that the surrounding environment would not have suffered any damage from the mining operation.

The social norms and legal mandates are much different today. The environmental movement which took place in the sixties and onward produced social recognition of environmental issues that resulted in a multitude of state and federal legislation. Companies are working with communities where they operate and wish 
to establish mines. All major mining companies have websites that are devoted specifically to their sustainable development policies.

Today sustainable development is defined not only in terms of environmental sustainability but in terms of the economic sustainability of the community where a mine will be located. According to Eggert, "even if a mine itself is not sustainable, in principle the economic benefits created by mining can be sustained indefinitely through appropriate investment in education, health care, infrastructure, and other activities that can create well being long after mining ceases" (Eggert, 2001, p. 4). The legacy of the mining industry evaluated on the basis of today's norms of environmental sustainable development is not good. Mining companies operated in the past in an era of different social norms and governmental regulation.

Using a broad definition of sustainable development, the purpose of this thesis is to determine if the Flambeau Mine in Ladysmith Wisconsin, owned by Kennecott Mining Company, a wholly owned subsidiary of Rio Tinto, can be categorized as an example of sustainable development. Sustainable development will include ecological sustainability, economic vitality, and social equity (Veiga, 2001), considered to be the three pillars of sustainable development. According to published literature, a mine cannot be considered sustainable if it does not meet these three criteria. In the report Industry in Transition: A Profile of the North American Mining Sector by Alistair MacDonald it is stated that "In order to appease both public demands and corporate necessities, mining firms have to look at sustainability in a new way that emphasizes it as a cost reduction, rather than cost addition exercise" (MacDonald, 2002, p. 111). To help attain the goal of a sustainable project, 
MacDonald believes that a company should be proactive in communicating with the local community and should complete a very detailed, in-depth local and regional analysis before proceeding with the project. The in-depth study would include not only locating the geological promising areas but also analyzing the project in terms of economics, social, cultural impacts and local politics.

The framework that will be used in the evaluation of the Flambeau Mine in terms of sustainable development has several components. The first part of the framework is whether local concerns were recognized before the project was started.

The second part of the framework that will be used is from the MMSD report that states that "the challenge is to ensure that the effect of interactions are regarded as positive by those affected locally as well as by the promoters of the project, and that communities develop in ways that are consistent with their own vision" (MMSD, 2002, p. 198). The physical resource, financial resources, human resources, information, community values and knowledge, and finally community institutions will be studied to determine whether the mine's contribution was sustainable for the local community and if the community was a better place after the mine than before.

The final report "Evaluating Mining and its Effects on Sustainability: the Case of the Tulsequah Chief Mine" provided additional assessment tools, the third part of the framework. In this report, author Tom Green developed nine criteria to analyze whether a proposed mine is sustainable. Those nine criteria are 1 . Need-Present Generation, 2. Future need, 3. Acceptable Legacy, 4. Full-Cost, 5. Contribution to economic development, 6. Equity, 7. Consent, 8. Respect for ecological limits, maintenance of ecological integrity and landscape requirements, 9. Offsetting 
Restoration. Each of these criteria will be applied in the evaluation of the Flambeau Mine. Using the above framework a conclusion will be presented as to whether the Flambeau Mine can be considered an example of sustainable development in the mining industry.

The final part of this thesis will be a comparison between Flambeau and other business's in Ladysmith and the failed attempt to mine at Crandon, Wisconsin. Both of these comparisons will be used to determine what aspects of the Flambeau project made it successful. Once these are presented a conclusion will be made as to whether the Flambeau Mine was indeed an example of sustainable development. Recommendations for future work will be discussed including what Kennecott can do to help make their Eagle Project successful. 


\section{CHAPTER 2}

\section{Literature Review}

Material relating to the specific question of the sustainability of the Flambeau Mine project in terms of its long-term benefits to the community is limited. Reports that were prepared by the company for the Flambeau Mine permitting process are available. Two such reports dealt with demographic and economic data for Rusk County, the City of Ladysmith, and the town of Grant prior to the Flambeau Mine operating. One of the reports was that of the State of Wisconsin Department of Natural Resources (WDNR) entitled Final Environmental Impact Statement Flambeau Mining Company Copper Mine Ladysmith, Wisconsin and the other was entitled Environmental Impact Report for the Kennecott Flambeau Project which had been completed by the consulting company Foth and Van Dyke. The Environmental Impact Report (EIR) analyzed factors such as population, taxes assessed, and income in the local area that could be impacted by the mining operation. The report made by the WDNR discussed these factors in more detail and presented alternatives for the mine design and how the alternatives might affect the community. It is interesting to note that all the analysis was undertaken before the mine was opened but that no analysis of the impacts occurred during or after the mining operation.

Other documents that were researched were in the area of sustainable development and its importance to communities. One such article was titled "Mining with Communities" and its premise was that for a mine to be considered sustainable, it needs to adhere to three principles which are ecological sustainability, economic vitality and social equality (Veiga, 2001). Theses principles should be adhered to not 
only for the life span of the mine but long after its closure. These principles will be used in the analysis of the Flambeau Mine in this research project. Another article that dealt with the subject matter was by Roderick Eggert and its title was "Mining and Economic Sustainability: National Economies and Local Communities". In this article Eggert described the importance of companies viewing sustainability as an important concept for their success. He also discussed the importance of having the local community's input on issues that concern them and determining how to deal with those concerns so that all parties involved will recognize the benefits of a mining project.

In the book Large Mines and the Community (McMahon \& Remy, 2001) the editors dealt with some of the issues that face small communities outside the United States. They provide some examples in Canada but most of the case studies were for Latin America and Spain. No formula or analytical procedure to determine sustainable development for a mine was found in any of the literature.

To determine the specifics of the mine at Ladysmith Wisconsin, it was necessary to read the history of the Flambeau project on Kennecott Minerals website. Yearly Social and Environmental Reports dating from 1999 through 2004 were studied. In each of those reports a synopsis of each of their active mines in the United States (three mines) as well as their five reclaimed properties was provided. These reports are considered by the company a "Case Study in Sustainable Development". The company's Health, Safety and Environment Policy, Sustainable Development Policy, and Community Policy as well as a company profile and Presidents Report were included in each Social and Environmental report. A Community Relations 
Plan 2005-2009 was also available which was used to gain information as to the future plans for the Flambeau site and Kennecott's involvement in the community. "The Kennecott Flambeau Communities Relations Plan (Plan) addresses the company's relationship with the surrounding communities, which include the City of Ladysmith, Rusk County and the Town of Grant, and focuses primarily on Flambeau's position within the communities as a reclaimed mining site and major landholder" (Murphy, 2004, p. 1). This report also briefly describes twelve goals that the company has for the years between 2005 through 2009. It describes other areas that the company is involved in such as economic development, recreation/health, and finally educational development.

\section{$\underline{\text { Sustainable Development }}$}

The basic concept of "sustainable development" was first brought up during a United Nation's Conference on the Human Environment which was held in Stockholm Sweden on June 5-16, 1972. This conference investigated the need for a common outlook and principles to guide in the preservation and enhancement of the human environment. At this conference many principles were written into the Stockholm Declaration. One principle in particular dealt with the extraction of natural resources (from the website: www.naturalresources.org/minerals/CD/sustdev.htm)

"States have, in accordance with the Charter of the United Nations and the principles of international law, the sovereign right to exploit their own resources pursuant to their own environmental policies, and the responsibility to ensure that activities within their jurisdiction or control do not cause damage to the environment of other States or of areas beyond the limits of national jurisdiction.". 
Based on this thinking, a meeting was held in 1987, the World Commission on Environment and Development (WCED) also called the Brundtland Commission. This group commissioned a report called "Our Common Future" which stated the most widely accepted definition of sustainable development which has already been quoted.

The United Nations Conference on Environment and Development (UNCED) held a meeting in Rio de Janeiro, Brazil in 1992 which is also called the Earth Summit. During this conference a plan was formulated called Agenda 21 which was an action plan to move the world toward sustainable development. In this document there were no specifics dealing with mining. Four sections were indicated: 1 . Social and Economic Dimensions, 2. Conservation and Management of Resources for Development, 3. Strengthening the Role of Major Groups, 4. Means of Implementation. The next meeting was held in 1997 to review the progress on meeting the goals of Agenda 21 which was called Earth Summit+5. The next major meeting dealing with questions of sustainable development and its role within the United Nations was the UN Millennium Summit held in 2000. There, Secretary General Kofi Annan presented his vision for the role of the UN in a new globalized world. Again mining was not mentioned directly in his report but it was indirectly referred to.

The final meeting that discussed sustainable development was the World Summit on Sustainable Development (WSSD). It marked the tenth anniversary of the 1992 Earth Summit (UNCED) and was held on August 26 thru September 4, 2002 in Johannesburg, South Africa. This conference is also called the Johannesburg 
Summit. The participating countries reviewed the progress on Agenda 21 and then they created two documents. One of those documents dealt directly with the mining industry and it was titled the "Plan Implementation for the World Summit on Sustainable Development". As a result many other documents were published by the United Nation's, national governments, the private sector, and non-governmental organizations (NGO's). One of those reports has been discussed earlier in this section, the MMSD. It provided major input to the summit process. Since this last summit in 2002, there have been no meetings dealing with sustainable development in relation to the mining industry.

Two other references were used. Both were developed by the Minerals and Sustainable Development Project (MMSD), a joint project between the World Business Council for Sustainable Development (WBCSD) and the International Institute for Environment and Development (IIED). The first report published through the project was titled "Breaking New Ground: Mining Minerals and Sustainable Development". It was an overview of the problems faced by the mining industry with regard to sustainable development and "integrating economic activity with environmental integrity, social concerns, and effective governance systems" (MMSD, 2002, p. xvi). It is stated that "In the context of the minerals sector, the goal should be to maximize the contribution to the well-being of the current generation in a way that ensures an equitable distribution of its costs and benefits, without reducing the potential for future generations to meet their own needs" (MMSD, 2002, p. xvi). 
The other report by the MMSD was entitled "Industry in Transition: A Profile of the North American Mining Sector" written by Alistair MacDonald. This report was "driven by a concern that a disconnect had emerged between mining/mineralsrelated practices and the values of today's society, they voiced a concern that their "social license" was in jeopardy" (MacDonald, 2002, p. v). It focused on five tasks specifically related to the North American mining sector: 1. the development of a story or profile of the North American mining industry, 2. development of a set of guidelines for sustainability, 3 . setting a timeline for the mining industry to adopt the principles of sustainable development, 4. developing future scenarios of the mining industry and 5. writing the final report. The section that is of most interest is the section on sustainability and what the North American mining sector can do to adhere to sustainability principles.

There have been many articles and books published on the topic of sustainable development. Most, if not all, discuss the fact that there is no concrete definition for the term sustainable development and how difficult it is to determine if a company, more specifically a mining company, can actually accomplish a policy of sustainable development.

Mining is an unsustainable activity because eventually the deposit will be depleted and the company must move to the next deposit. This basic contradiction seems to be a reason why not much literature dealing specifically with indicators of sustainable development in the mining sector is evident.

However two articles were published by the MMSD discussing the benefits of a sustainable company policy. One was entitled "Sustainability Indicators and 
Sustainability Performance Management" by Professor A. Warhurst and the other was entitled "Financial Incentives for Improved Sustainability Performance: The Business Case and the Sustainability Dividend" by Maryanne Grieg-Gran. The first article by Warhurst is about "the development and use of Sustainability Performance Indicators (also referred to as Sustainability Indicators) to communicate to the internal and external stakeholders of mining companies the extent to which their mining activities are contributing to, or detracting from, sustainable development goals" (Warhurst, 2002, p. 3).

The premise of the article by Grieg-Gran was whether there is a financial incentive for a company to "strive for good environmental and social performance?" (Grieg-Gran, 2002, p. 3). Both of these articles build on one another and both will be used in the framework to investigate the sustainability of the Flambeau project.

An article that solidifies the history of sustainable development is by Herman Daly and it is entitled "Sustainable Development: From Concept and Theory to Operation Principles". Daly states that "lack of a precise definition of "sustainable development' is not without benefit. It has allowed a considerable consensus to evolve in support of the main idea that it is both morally and economically wrong to treat the world as a business in liquidation" (Daly, 1990, p. 32). The article finds that it is not in a company's best interest to operate as they might have done in the past. This article was published in the early stages of the development of the concept of sustainability. This particular policy is becoming more widely accepted.

There are another six articles that were reviewed on the topic of sustainable development and its specific application to mining and mineral development. 
Richards (2002) stated that "simply doling out cash is not a sustainable solution, and modern mining operations now expend considerable resources in social infrastructure investment (e.g., in schools, hospitals, roads, secondary industry development, and most importantly, business and technical training) to ensure that money paid in compensation is not wasted, and that an investment is made in the future of the society after inevitable mine closure" (Richards, 2002, p. 5). The other five articles detail the history of the logical progression of the concept of sustainable development.

The final article that was reviewed was a case study on sustainability. It is titled "Evaluating Mining and its Effects on Sustainability: the case of the Tulsequah Chief Mine" and it was written by Tom Green (2001). The Tulsequah Mine is located in the province of British Columbia (B.C.) and is 100 kilometers (km) due south of Atlin B.C and $64 \mathrm{~km}$ northeast of Juneau Alaska and is located directly on the Tulsequah River. The mine was originally opened from 1951-1957. It produced copper, gold, lead, silver, and zinc. The company that owns the mine wanted to investigate reopening it. Many environmental concerns existed which are similar to those of the Flambeau Mine. In both locations there was a concern about Acid Mine Drainage. While this study was undertaken before approval was given for its reopening, it will be shown that the framework that Green developed can also be used to analyze a closed mine. Green stated: "this report helps fill two gaps: the lack of a rigorous sustainability assessment framework for proposed mineral developments, and the need for a sustainability assessment of the proposed TCM (Tulsequah Chief Mine)" (Green, 2001, p. 2). In the report there are nine sustainability criteria that 
were developed to asses the sustainability of, in this particular case, the proposed mine. In respect to the Flambeau mine these nine criteria will be used to assess whether the Flambeau Mining Company adequately addressed these criteria which would deem it as a sustainable project. Those nine criteria are:

1. Need-Present Generation

2. Future Need

3. Acceptable Legacy

4. Full-Cost

5. Contribution to Economic Development

6. Equity

7. Consent

8. Respect to ecological limits, maintenance of ecological integrity and landscape requirements

9. Offsetting Restoration

Each of these nine criteria will be explained as to their significance. The first criteria, needs of the present generation looks at whether there is a need to actually mine the deposit and not just for profits for the company. This would mean that society needs this material to produce some product. The next criteria, future need determines if "exploiting the deposit in question now does not deprive future generations of access to deposits of sufficient quality that they will be able to extract minerals to meet their needs" (Green, 2001, p. 34). Criteria 3 relates to the criteria of acceptable legacy whether future generations will have to clean-up some type of environmental mess due to this mine operating. In the criteria of full-cost "one of the key requirements for achieving sustainability is that producers pay the full costs of their economic activity using a precautionary stance" (Green, 2001, p. 35). The contribution to economic development deals with the diversification of the local economy because the company knows that the mine will only be open for a limited time. The equity part of the criteria deals with the benefits of the mine and how they 
are shared with not only the company's employees' but whomever is affected by the mine. This specific criteria is taking the definition of sustainable development to the next level (for the mining industry) because it deals with both this and future generations, as specifically included in the definition of sustainable development. The consent of the local community is very important in the nine criteria for sustainability. It is important to gain community consent before the mine is opened. Numerous articles have stated the importance of giving the local community opportunities to comment and make suggestions on proposed mine projects. The final two criteria deal with the mine after it closes and the status of remediation. Both seek to make sure that the company takes into consideration the remediation plan for the site after the mine closes and what it will look like. It is making sure that the natural ecosystem, as well as biodiversity is protected as much as possible and not affected negatively.

The final resource for this project is the Northwest Regional Planning Commissions report entitled "A Socioeconomic Study of the Flambeau Mine Project." This was a study to determine the amount Kennecott paid in taxes and how local units of government used the funding. A good history of the entire project was gained from this report because it was so thorough and the fact that a twelve year period was available for assessment.

It should be explained that whenever Kennecott or Flambeau Mining Company is used, the term is referring to the same organization. Flambeau is a wholly owned subsidiary of Kennecott Mining Company and the names are used interchangeably. 


\section{CHAPTER 3}

\section{Geology}

Most of the state of Wisconsin's bedrock is covered by glacial deposits that age from about 1 million to 10,000 years before present (WDNR, 1990). These glacial deposits overlay Cambrian age sandstone. This sandstone grades from pebbly to very fine grained in Rusk County and is roughly a few feet to 100 feet thick. The underlying layer is Precambrian bedrock that consists of metamorphosed volcanic, granitic and sedimentary rocks. These metamorphic rocks in Rusk County are steeply dipping belts that are east northeast trending. The Flambeau deposit is located on one of the belts and it extends from the Pembine area in Florence County to Ladysmith.

The Flambeau deposit is tabular in shape and vertically dipping (Mercando, 1991). It is 2,400 feet long and it ranges in thickness from 20 to 200 feet and it extends to a depth of 600 to 800 feet (WDNR, 1990). The Precambrian rock (which includes the orebody) is a complex of interfingered metamorphosed volcanic flows, and other ejected volcanic material. They were then strongly altered and put through intense folding and faulting. These volcanic rocks were eroded, weathered and then the top was supergene enriched (Mercando, 1991). The supergene enrichment is a process where there was fluctuating levels of mildly acidic groundwater that weathered the rock to form different minerals. This altered the Precambrian rock from 50 to 400 feet below the bedrock surface. The actual rock types within this mineralized zone are quartz rich sediments and volcanic ash, massive sulfide, semi massive sulfide and chert. The deposits that are economic to mine are copper sulfide minerals: chalcocite $\left(\mathrm{Cu}_{2} \mathrm{~S}\right)$, bornite $\left(\mathrm{Cu}_{5} \mathrm{FeS}_{4}\right)$, and chalcopyrite $\left(\mathrm{CuFeS}_{2}\right)$ with trace 
amounts of gold and silver (WDNR, 1990). These minerals are present from 50 to 225 feet and that is the deposit that was mined (Mercando, 1991).

\section{$\underline{\text { History of Mining in Wisconsin }}$}

At present there are currently no metallic mines in operation in the state of Wisconsin but that does not mean that the state does not have a rich history when it comes to hard rock mining. Even the nickname the "Badger State" is a reference to mining by the early lead miners that lived in homes dug out of hillsides, similar to what a badger would live in and so the name stuck (Roe, 1991). Also, both the Coat of Arms and Great Seal of the state have a miner, picks and shovels, and pyramid of stacked metal on them also showing the importance of mining to the history of the state. In 1971 galena was made the state mineral.

The Indians were the first to discover and dig the lead ore but it was the French-Canadians who showed them how to smelt the ore. The mineral they were finding was galena $(\mathrm{PbS})$ or lead sulphide. The French-Canadians helped the Indians separate the lead from the sulphide, also called smelting, to make metallic lead that had a high value for bullets. The years 1690 through 1698 are considered to be the beginning of Wisconsin's' mining efforts (Roe, 1991). In 1824 the first permanent mining settlement at New Diggings in Lafayette County and at Hazel Green in Grant County were established. In addition to these two locations, there are many early settlements that have their origins based on mining:

$\begin{array}{lllll}\text { New Diggings } & \text { Black Leg } & \text { Shullsburg } & \text { Mineral Point } & \text { Platteville } \\ \text { Beetown } & \text { Black Jack } & \text { Benton } & \text { Lead Mine } & \text { Calamine } \\ \text { Swindler's Ridge } & \text { Little Patch } & \text { Pin Hook } & \text { Hardscrabble } & \text { Red Dog } \\ \begin{array}{l}\text { Big Patch } \\ \text { (Roe, 1991) }\end{array} & \text { Rockville } & \text { Shake Rag } & & \\ & & & & \end{array}$


Currently there are no lead or zinc mines in the state of Wisconsin and the last mine in operation was the Eagle-Picher mine near Shullsburg which closed in 1979. That date marked the end to continuous lead-zinc mining in the state that began around 1820-1840. When the Jackson Iron Company ceased operations near Black River Falls in 1983 it marked the last commercial production of any metallic ore in the state until the Flambeau Mine started production in 1991.

The first phase of mining in the state was for lead and the second was for zinc. Most of the time, lead and zinc were mined together. This mining began in 1860 near Highland, Wisconsin. In 1911 Wisconsin ranked third in U.S. production of zinc. In 1916 there were 80 zinc mines that produced 219,128 tons and by 1938 only 2,000 tons were produced.

The third major metal that was mined in Wisconsin was iron. The main districts in the state that produced iron ore were the Mayville District which had mines operating from 1849 through 1928, the Gogebic Range (1884-1962), the Menominee Range (1877-1955), the Baraboo Range (1904-1925), and finally the Black River Falls District (1857-1983). Once the Jackson Iron Company closed there were no more iron mines in the state.

Before the Flambeau Mine opened there was no history of copper mining ever being done in the state. The copper bearing formation of the Lake Superior region has large surface exposures in northern Wisconsin and it was assumed those would be profitable. Native copper has been found in areas extending from Michigan across Wisconsin to the Minnesota boundary. There were a few attempts at mining copper before the Civil War but nothing ever proved to be commercially viable. 
At present there is an estimated 2,000 non-metallic mines in the state of Wisconsin. It is the only type of mining done in every state. A nonmetallic mine is one that not only provides aggregate for construction, sand and gravel and crushed stone (limestone and dolomite) for road maintenance and road building, dimension stone for monuments, volcanic andesite for shingles, peat for landscaping, industrial sand for use in the oil industry, as well as many other uses not mentioned here (WDNR, 2005). Nonmetallic mining is a widespread activity in the state which is in part due to the variety of geologic environments. This industry is regulated to make sure that each mine has a reclamation program which is locally administered but those rules and laws are separate from the metallic mining laws and rules.

Besides actual mining, some organizations were created to help the industry or to supply engineers to the industry. On March 25, 1853 the state legislature created the Wisconsin State Geological Survey for the economic development of its natural resources. Then in 1871 the Department of Mining and Metallurgy was created at the University of Wisconsin. In 1907 the state legislature passed an Act establishing a trade school for mining at Platteville. On January 27, 1908 the Wisconsin Trade Mining School opened in Platteville Wisconsin. This particular school changed its name in 1915 to the Wisconsin Mining School and again in 1964 it was changed from Wisconsin State College-Platteville to Wisconsin State University-Platteville (UWP) which is its current name. Unfortunately mining engineering is no longer offered at the University. When reflecting on the history of the mining industry Roe quoted a scholar who said "Mining in Wisconsin is more than a sequence of discovery, 
exploitation and abandonment; it is also the opening of a territory, the settlement of a frontier and the growth of a region" (Roe, 1991, p. 4).

A History of Wisconsin Mining by Lawrence Roe reviews the entire history of mining in the state of Wisconsin. It is important to understand the context of mining in the state before the Flambeau project was begun. The Flambeau Mine was the first copper mine in the entire state and the first metallic mine to operate since the Jackson Iron Company (a wholly owned subsidiary of Inland Steel Company) ceased operation in 1983 (Roe, 1991). According to Roe there are four other major metallic deposits in the state: the Crandon zinc-copper deposit, Kennecott's Thornapple copper-zinc deposit, Pelican copper-zinc deposit (Noranda Exploration), and the Bend Project which is again a massive sulphide deposit. It should be noted that there are a total of five deposits that had been discovered in a 20 year time span but only one of those deposits (Flambeau) developed into a profitable mine.

\section{History of the Flambeau Mine}

The Flambeau Mine in Ladysmith Wisconsin is still owned and was operated by the Flambeau Mining Company which is a wholly owned subsidiary of Kennecott Minerals Company. Kennecott in turn is a wholly owned subsidiary of Rio Tinto Mining Company which is based in London, England. Rio Tinto is one of the world's largest mining companies and Kennecott is one of six global business units. The Flambeau Mine is located 1.7 miles south of the town of Ladysmith, Wisconsin and 140 feet from the Flambeau River. It was the first metallic sulfide mine to be permitted under the state of Wisconsin's recent laws. It is advertised as an example of community/company relationship which resulted in sustainable development. 
This particular orebody was first discovered in 1968. Originally, the project was planned to last 11 years, the mine to have a total depth of 300 feet with a tailings management facility, concentrator and to have the pit reclaimed as a lake.

Community concerns related to the ore processing on site, environmental protection of the Flambeau River and leaving the pit as a lake led the Company to reevaluate the project (Kennecott, 2001). This in part led to the company withdrawing their permit application until the mid 1980's when the plan was redesigned with the community's input in mind.

There was major opposition to mining in Wisconsin in the late 1970's. When Kennecott submitted their initial Environmental Impact Statement to the Wisconsin Department of Natural Resource (WDNR) in 1976, Exxon discovered the Crandon deposit (NWRPC, 2005). It was then that anti-mining sentiment surfaced. Rusk County passed an ordinance banning sulfide mining during that same year and in 1977 Kennecott withdrew their permit application for the reasons stated above and due to falling copper prices.

Throughout the subsequent permitting process in the late 1980's the protection of the Flambeau River was an integral part of the company's design work. As part of that concern the Company included the following features in the planned design, operation and closure of the Flambeau Mine:

- Mining in as small a footprint as possible covering only 181 acres

- Utilization of a state-of-the-art water treatment facility, which produced over 600 million gallons of high quality water, discharged to the Flambeau River

- Minimizing environmental impacts through use of high-density polyethylene liners, leachate collection systems, treatment of contact water and sorting waste rock 
- Controlling the formation of Acid Rock Drainage (ARD) from high sulfide waste rock and backfill material

- Backfilling the open pit in the same geologic sequence and establishing onsite native plant communities for wildlife habitat and hiking trails for passive recreation

- Reclaiming the mine site to an environmentally stable condition with sustainable biodiversity

(Kennecott, 2002)

Along with the features stated above, the Flambeau Mining Company also completed a Local Agreement and Land Use Permit in August 1988 with the governments of Rusk County, City of Ladysmith, and the Town of Grant. Most of the agreement and permit were to formalize guarantees to the local communities involving the following:

- Hiring of Employees-Flambeau and its contractors committed to hire at least 75 percent of employees from within ten miles of the Rusk County border. Flambeau averaged over 80 percent local hire during the project.

- Visitors Observation Area-Flambeau agreed to provide an area to allow visitors to park and observe the mining operation. The Flambeau Visitors Center was located on the topsoil stockpile providing a clear view of the operation and site reclamation. Over 125,000 visitors observed the operation and reclamation of the Flambeau Mine over five years.

- Hours of Operation-Blasting, crushing, and rail shipping were limited only to daylight hours, Monday through Saturday.

- Guarantee of Private Off-site Wells-Flambeau agreed to test potable wells within a Well Guarantee Area. During the project, there were no wells within the guarantee area that failed to be suitable for human use.

- Right of First Refusal-The local governments have the first right of refusal based on the highest bid received on any property being sold by Flambeau.

- Revenues to Local Governments-One-time construction payments of \$100,000 were paid to the local governments. (this occurred once)

(Kennecott, 2002)

Permits for the Flambeau Mining Company were approved by the Wisconsin

Department of Natural Resources in January 1991. Construction began that spring.

In May 1993 the first shipment of ore left the site and the last shipment was made in

August 1997. During that time 1.8 million tons of ore were removed including 
181,000 tons of copper, 334,000 ounces of gold, and 3.3 million ounces of silver.

The total depth of the mine was 220 feet. Flambeau Mining Company had an initial capital investment of about $\$ 60$ million which included the money to build the wastewater treatment plant. Net sales were $\$ 341$ million with $\$ 152$ million for operating costs. Sixty four million was paid in federal, state and local taxes. The net income approximated \$125 million. Flambeau has spent approximately \$20 million on reclamation and rehabilitation (NWRPC, 2005). The following table lists estimated values of yearly dollars earned when the Flambeau Mine was in operation and the amount paid in Net Proceeds Tax (NPT):

Table 1: Summary of Earnings from Copper Production at Flambeau Mine

\begin{tabular}{|l|l|l|l|l|l|l|}
\hline Year & $\begin{array}{l}\text { Production } \\
\text { (metric } \\
\text { tons) }\end{array}$ & $\begin{array}{l}\text { Production } \\
\text { (pounds) }\end{array}$ & $\begin{array}{l}\text { Average } \\
\text { Price/Lbs }\end{array}$ & Earnings & Taxes Paid & \\
\hline 1993 & 20,000 & $44,092,400$ & 0.91 & $40,124,084$ & $502,568.18$ & \\
\hline 1994 & 40,000 & $88,184,800$ & 1.11 & $97,885,128$ & $6,390,478.63$ & \\
\hline 1995 & 40,000 & $88,184,800$ & 1.38 & $121,695,024$ & $6,406,889.28$ & \\
\hline 1996 & 30,000 & $66,138,600$ & 1.09 & $72,091,074$ & $1,070,627.20$ & \\
\hline 1997 & 18,000 & $39,683,160$ & 1.07 & $42,460,981.20$ & No record & \\
\hline & & & & & & \\
\hline
\end{tabular}

Source: USGS Mineral Commodity Worksheets and Jana Murphy

The above chart shows the rough estimate of how much money was earned from only copper production at the Flambeau Mine. There was a tax adjustment for the years 1993-1995 that totaled approximately $\$ 27,000$. That amount was in excess of the amount in the above chart. There was no record of NPT paid in 1997. The first year the mine was in production there was a very low average copper price but the company still made about $\$ 40$ million. Considering this was a small deposit they made in excess of $\$ 300$ million dollars in less than 4 years and the local community received approximately $\$ 14$ million dollars in NPT for the life of the mine. There is 
an explanation of the NPT and Mining Investment and Local Impact Fund in Chapter 4.

Once mining ended in late 1996 the pit was backfilled with the same material that was taken out in the same order $(5,000,000$ cubic yards of mined rock and soil) to put the land in basically the same condition as it was before the mining operation commenced. The process was basically complete by the fall of 1997 . During 1998 the contours were reestablished, topsoil replaced, wetlands constructed, and seeding/planting started. When visiting the site a visitor would never know that a mine existed because the area has been revegetated. According to Kennecott Minerals 2000 Social and Environmental Report "Today, the reclaimed mine site is composed of 125 acres of tall grass prairie, 15 acres of woodlands, and over 10 acres of wetlands. Revegetation of the mine site began in 1998 following backfilling of the open pit and recontouring of the site. Over 100 native plant species were installed either as seed or plants on the reclaimed mine site" (Kennecott, 2000, p. 33). The plan was to make sure that there was not a large impact on the land. The company has already submitted its Notice of Completion to the Wisconsin Department of Natural Resources (WDNR) in 2001 and is expected to petition for the Certificate of Completion in 2006 (Murphy, 2005). 


\section{CHAPTER 4}

$\underline{\text { Analysis }}$

The first part of the framework that will be used in this analysis is based on the Mining, Minerals and Sustainable Development (MMSD) publication titled Industry in Transition: A Profile of the North American Mining Sector. In this article by Alistair MacDonald it was stated that for a company to be sustainable in a community it must be proactive in communicating with that community. The company should also complete a very detailed in-depth local and regional analysis before the project is started. The indepth study would not only look at the geology of the area but also the economic, social, cultural and political impacts of the mining project.

The Flambeau Mining Company analyzed all of these criteria in its Environmental Impact Report (EIR) which was prepared by the consulting firm Foth and Van Dyke. The report not only has sections devoted to the geology of the area but also contained scenarios relative to alternatives to mining. One was the no action scenario. They also investigated the impact of surface facilities, various alternatives for reclamation and final land use alternatives. Other major sections that were included in the EIR discussed climatology, meteorology, and air quality. There was a major section devoted to groundwater studies that focused on a hydrogeologic analysis of not only the region but the project site. They also studied the surface water and bottom sediments of the Flambeau River and how the river affects the hydrogeology of the area. A study of the effect on aquatic biology, terrestrial biology, ambient noise, land use, aesthetics, and socio-economics was also included. A main section of the report analyzed the environmental impacts. The final main section covered mitigation of impacts which 
analyzed how to solve and/or prevent negative impacts from occurring due to the project. In 1989 Kennecott provided the EIR to the Wisconsin Department of Natural Resources (WDNR) which was responsible for providing the final EIR to the appropriate federal and other state agencies. The EIR was submitted to support the mining permit application for the Flambeau project.

Kennecott requested the following of the WDNR "1. Prepare and finalize a draft and final Environmental Impact Statement (EIS) for the proposed project described in the EIR and mining permit application. 2. Coordinate with the federal agencies to assure that the department's EIS will be responsive to the needs of federal agencies that have permitting jurisdiction over the proposed project. 3. Review and approve all permit applications, license applications, and similar documents regarding the proposed project that are filed with and require approval of the department" (Foth and Van Dyke, 1989, letter to WDNR).

Before a company can apply for a mine permit they must issue a Notice of Intent to the Wisconsin Department of Natural Resources (WDNR). This is a document that indicates that the company has an interest in developing a mine and will start collecting data for a mining permit application (WDNR, 2005a). Between 45 and 90 days after issuance of the Notice of Intent the department holds a hearing in the county where the mine is proposed to gather public comments on the project. Some of the issues that could be discussed are anticipated environmental impacts, important environmental resources, and socioeconomic issues specific to the area.

As part of the mining permit application a company must submit the EIR, a feasibility report for any mining waste facilities and other necessary permit applications 
(WDNR, 2005a). The EIR was used by the WDNR to analyze the likely environmental impacts of the Flambeau project and to write what is known as an Environmental Impact Statement (EIS). In the EIS it is stated that "the proposal and associated impacts may change depending upon the final permit decisions and the conditions attached to any permits" (WDNR, 1990, p. ii) The EIS “assists the Department in making regulatory decisions, the EIS does not determine whether the project is approved. Decisions on the project are made by reviewing permit applications and determining if the project would meet state regulations. If the technical review concludes that the project would meet the criteria established in the regulations, the Department must, by law, issue the permits" (WDNR, 1990, p. i). This is an important step in the permitting process because it analyzes objectively any positive or negative impacts from the proposed project. There were four sections to the Mining Permit Application at the time Kennecott applied. These included a mining plan, a reclamation plan, a monitoring and quality assurance plan, and finally a risk assessment. Since the Flambeau Mine project two extra components have been added; one which demonstrates compliance with s. 293.50, Stats. (Mining Moratorium Law) and the other is an irrevocable trust agreement proposal (WDNR, 2005a). The requirement for these components was added in 1998 and 2000 respectively. Once the DNR deems the application to be complete they then prepare a Draft Environmental Impact Statement (DEIS). A public meeting is held 30 to 60 days after the release of the DEIS for public comments and the public has 90 days to submit in writing their comments to the department. When the Final Environmental Impact Statement is written the Master Hearing must be scheduled between 120 and 180 days after it is made public. The Master Hearing has two parts one is for the public to make 
comments and the other a formal case portion where witnesses are under oath and subject to cross-examination (WDNR, 2005a).

In the specific case of the Flambeau Mine, the public had the opportunity to comment on the DEIS from September 6, 1989 through October 23, 1989 and the department received 70 individual comment letters and 2 form letters. The public information meeting was held on October 6, 1989 and there were 44 verbal statements and 5 written statements regarding the mine. Some of the comments received by the WDNR are included in the Appendix of the Final Environmental Impact Statement and deal with specifics in the report not the whether they supported the mine.

Another place the pubic had the opportunity to comment on the mine was in the negotiations for the Local Agreement and Land Use Permit. In 1988 the state changed the mining law to allow local municipalities to enter into a contract between themselves and the mine operator (WDNR, 2005d). The impetus for passing this law was due to the negotiations for the Flambeau Mine. The "local agreement could specify the conditions, terms, restrictions, safeguards and other requirements for the proposed mine which the municipality believed necessary for protecting the public health, safety or welfare of its residents" (WDNR, 2005d, p. 2). When Kennecott tried to permit the mine in 1976 it was met with heavy protests. The people and state were concerned with protecting the environment and improving their quality of life (NWRPC, 2005). In March 1976 the WDNR held a public hearing where many residents felt that their input was not taken into consideration. The Rusk County Board unanimously passed a temporary ban on mining in the county because as part of the mine permit approval a company must comply with zoning regulations in all the affected communities. The result was the department tabled 
the hearings indefinitely and Kennecott deferred the project sighting falling copper prices.

When the project was reexamined in 1986 the project was redesigned to meet the requirements of the local units of government to protect groundwater and the Flambeau River (NWRPC, 2005). The Governor of the state then formed a Task Force which included local citizens and local officials from Rusk County to review local concerns about the proposed project. The Task Force met over a 3 month period and its recommendation was that representatives from Rusk County, Ladysmith and Town of Grant meet with representatives from Kennecott Minerals Company to discuss their mutual concerns. A committee was formed in October 1987 and after 10 months an agreement was reached. By law the Local Agreement has to be voted on by the public. It was discussed and debated by the Ladysmith City Council, Town of Grant Board, and the Rusk County Board of Supervisors. They each held hearings and talked to their constituents about the local agreement and approximately 500 people spoke at the public hearings. Although there was public testimony against the mine the Local Agreement and Conditional Land Use Permit was signed by the negotiating committee on August 1, 1988 (NWRPC, 2005). It was then ratified by the Rusk County Board 14-4, Town of Grant Board 3-0, and Ladysmith City Council 6-1.

From analyzing the preceding information it should be noted that the Flambeau Mining Company adhered to the letter of the law at the time of application. However the company participated in the negotiations prior to the 1988 law encouraging this action.

The Flambeau Mining Company adhered to MacDonald's requirement for sustainability of providing an in-depth analysis of the mining project as required in 
Wisconsin's mining permit application process. With regard to being proactive with the local community the company followed the 1988 Wisconsin Law allowing for a local agreement. If such a law had not been passed, the question remains whether the company would have communicated as much with the local community before the mine was permitted.

The second part of the framework is also from a MMSD report Breaking New Ground: Mining, Minerals, and Sustainable Development states that "the challenge is to ensure that the effects of interactions are regarded as positive by those affected locally as well as by the promoters of the project, and that communities develop in ways that are consistent with their own vision" (MMSD, 2002, p. 198). How this challenge was met by Kennecott Minerals will be analyzed in great detail in the following sustainability section of this paper. The Local Agreement that was signed by the company and the local units of government was an indication of their mutual satisfaction.

"Evaluating Mining and its Effects on Sustainability: The Case of the Tulsequah Chief Mine" by Tom Green provided the third part of the framework for evaluation of sustainability. Green's nine criteria include:

\section{$\underline{\text { Need-Present Generation }}$}

With regard to this criterion it must be proven that our generation needs this material. Accordingly "need is the requirement for virgin minerals in order to provide for a sufficient and ecologically sustainable existence for the present generation once all reasonable efforts towards the efficient use of the previously extracted stock of mineral have been made" (Green, 2001, p. 34). In the Tulsequah case study Green proposes three dimensions that need to be met for "Present-Need" to be established. 
1. The Mineral in question contributes significantly to human well-being

2. The Mineral in question contributes significantly to prospects of sustainability

3. Finally that the minerals produced by the mine are required over the short to medium term.

While analyzing aspects of these three criteria it was necessary to use the United States Geological Survey (USGS) Mineral Yearbooks for the years that the Flambeau Mine was in operation. The years that will be referenced are from 1994 through 1997. The USGS website that has copper statistics and information says that copper is one the oldest metals used and it has been extremely important to the development of human civilization (USGS, 2005). Also, its physical properties of high ductility, malleability, thermal conductivity, electrical conductivity, and finally its resistance to corrosion have made it the third most consumed industrial metal after iron and aluminum respectively. Copper is used in building construction, electronics and electronic products, transportation, industrial machinery, and finally consumer and general products.

In the years that the Flambeau Mine was open the United States was the worlds second largest producer of copper (Edelstein, 1994). The US as a whole accounted for between 17 to 19 percent of world production and of that, 17 to 18 mines accounted for 98\% of that number (around 2.07 million metric tons in 1997). Consistently Flambeau Mine was ranked in the top 18 of that list. Here is the specific year, rank and capacity of the Flambeau Mine: $1994-14^{\text {th }} 40,000$ metric tons, $1995-13^{\text {th }} 40,000$ metric tons, $1996-$ $15^{\text {th }} 30,000$ metric tons, and finally $1997-15^{\text {th }} 18,000$ metric tons. In 1997 the mine closed so that is why the capacity dropped so dramatically from the year before. As far 
as supply and demand is concerned in 1994 demand was larger than the supply and worldwide copper inventories were reduced by 360,000 tons (Edelstein, 1994). The supply/demand curve for 1995 was in balance and in 1996 world inventories continued a downward trend. In 1997 the stock levels fluctuated and then started to increase (Edelstein, 1997) and it peaked at 1 million tons. After that the Flambeau Mine closed.

With regard to the first criteria, the contribution to human well being there is not enough information to determine whether the Flambeau Mine met this particular aspect of the criteria. In regard to criteria two whether copper contributes significantly to prospects of sustainability is beyond the scope of this study. There is enough information to determine that copper is needed in our society. The United States is consistently the worlds' largest consumer and producer of refined copper so every bit of production helps. The US did import copper from Chile during this time. The Flambeau Mine production was not sufficient to prevent the need for imports, thus copper from Flambeau was needed by society.

\section{$\underline{\text { Future Need }}$}

For this criterion it is necessary to show that mining at Flambeau does not jeopardize the ability of future generations to meet their needs. According to the USGS Mineral Commodity Summary for the years of 1997 and 1996 world total reserves of copper were 310,000 metric tons for both years. The reserve base was total 610,000 metric tons in 1997 and 1996. In both 1996 and 1997 world total land-based copper resources were estimated to be 1.6 billion tons and another 0.7 billion tons in deep sea nodules. By definition a resource is "a concentration of naturally occurring solid, liquid, or gaseous material in or on the Earth's crust in such form and amount that economic 
extraction of a commodity from the concentration is currently or potentially feasible" (USGS, 1980, p. 1). In that same circular a reserve base is "that part of an identified resource that meets specified minimum physical and chemical criteria related to current mining and production practices, including those for grade, quality, thickness, and depth. The reserve base is the in-place demonstrated (measured plus indicated) resource from which reserves are estimated. It may encompass those parts of the resources that have a reasonable potential for becoming economically available within planning horizons beyond those that assume proven technology and current economics. The reserve base includes those resources that are currently economic (reserves), marginally economic (marginal reserves), and some of those that are currently subeconomic (subeconomic resources). The term 'geologic reserve' has been applied by others generally to the reserve-base category, but it also may include the inferred-reserve-base category; it is not a part of this classification system" (USGS, 1980, p. 2). Finally the definition of reserves is "that part of the reserve base which could be economically extracted or produced at the time of determination. The term reserves need not signify that extraction facilities are in place and operative. Reserves include only economically and technically recoverable materials; thus, terms such as 'extractable reserves' and 'recoverable reserves' are redundant and are not a part of this classification system" (USGS, 1980, p. 2). Another publication from the Society for Mining, Metallurgy, and Exploration (SME) entitled "A Guide for Reporting Exploration Information, Mineral Resources, and Mineral Reserves" includes definitions for reserves and resources. In that article a mineral resource is "a concentration or occurrence of material of intrinsic economic interest in or on the Earth's crust (a deposit) in such form and quantity that there are 
reasonable prospects for eventual economic extraction. The location, quantity, grade, geological characteristics and continuity of a Mineral Resource are known, estimated or interpreted from specific geological evidence and knowledge. Mineral Resources are sub-divided, in order of increasing geological confidence into Inferred, Indicated and Measured categories. Portions of a deposit that do not have reasonable prospects for eventual economic extraction must not be included in a Mineral Resource" (SME, 1999, p. 6). In the same publication a definition for a mineral reserve is "the economically mineable part of a Measured or Indicated Mineral Resource. It includes diluting materials and allowances for losses which may occur when the material is mined. Appropriate assessments, which may include feasibility studies, have been carried out and include consideration of and modification by realistically assumed mining, metallurgical, economic, marketing, legal, environmental, social and governmental factors. These assessments demonstrate at the time of reporting that extraction is reasonably justified. Mineral Reserves are sub-divided in order of increasing confidence into Probable Mineral Reserves and Proved Mineral Reserves” (SME, 1999, p. 8). As can be seen from these two publications, USGS and SME, the definitions are similar but the SME ones are more precise. In the following table there is a list of global reserves and resources from 1996 through 2005.

Table 2: Global Copper Reserves and Resources

\begin{tabular}{|l|l|l|l|l|l|l|l|l|l|l|}
\hline Year & 1996 & 1997 & 1998 & 1999 & 2000 & 2001 & 2002 & 2003 & 2004 & 2005 \\
\hline $\begin{array}{l}\text { Reserves } \\
\text { (thousand } \\
\text { metric } \\
\text { tons) }\end{array}$ & 310 & 310 & 320 & 340 & 340 & 340 & 340 & 480 & 470 & 470 \\
\hline $\begin{array}{l}\text { Resource } \\
\text { (billion } \\
\text { metric } \\
\text { tons) }\end{array}$ & 1.6 & 1.6 & 1.6 & 1.6 & 1.6 & 1.6 & 1.6 & 1.6 & 1.6 & $\begin{array}{l}\text { More } \\
\text { than } \\
1.6\end{array}$ \\
\hline
\end{tabular}


From: USGS Mineral Commodity Summaries-Copper, for years 1996-2005

Based on the above numbers from the Mineral Commodity Summaries there is an abundance of copper mineral reserves left in the world after the Flambeau Mine deposit was mined. During mining (between 1993-1997) the mine produced 181,000 tons of copper, 334,000 ounces of gold, and 3.3 million ounces of silver. In comparison to the numbers in table 1 the amount produced would not have affected world reserves that drastically. According to the geological cross-section of the Flambeau deposit there is still some low grade massive sulfide copper left in the subsurface. Kennecott produced only from the high-grade deposit so if in the future more copper would be needed some other company could mine that part of the deposit. Unfortunately the USGS summary did not delineate between the high grade deposits and the low grade deposits. Because Flambeau Mining Company did not produce from the entire deposit it can be said that it would not be economical for another company to mine the lower grade ore. The major economic benefits from the project happened when the $10 \%$ copper was mined and the local community will lose out if and when the lower grade ore is mined. If that lower grade copper is mined it has already been determined in the FEIS from the WDNR that it would have to be processed on-site to make the project economical. That exact situation was what the local community prevented when the Local Agreement was signed. It seems therefore that it is unlikely that the low grade ore will be mined in the future as it would either be uneconomical for the company or the community would have to accept processing on site.

However, the conclusion can still be made that there is a plentiful supply of copper worldwide and that there should be no shortage of the metal for future generations 
to use and develop. The conclusion can be drawn that the Flambeau Mine did meet the sustainable criteria of future need. Mining this particular deposit did not adversely affect future generation's ability to meet their copper needs.

\section{$\underline{\text { Acceptable Legacy }}$}

This part of the criteria deals with the environmental legacy of the project. To be considered sustainable a mine has to be "developed in such a way that there is low risk that future generations will be burdened by the need to undertake ecological restoration, or by the need to provide ongoing treatment and decontamination of site discharges" (Green, 2001, p. 35). As was stated previously Kennecott and the State were very aware of the environmental implications of mining approximately 140 feet from the Flambeau River. When the company originally submitted a permit to the WDNR (1976) for this project, the local community objected because it feared pollution of the Flambeau River. At that time the economic climate was not favorable and the company withdrew the permit application. In the late 1980's Kennecott returned and again began the permitting process with a redesign of the project. As part of this new effort the company signed a Local Agreement and Conditional Land Use Permit with the local governmental organizations (i.e. Rusk County, City of Ladysmith, and Town of Grant). The agreement included stipulations under which Kennecott agreed to test potable wells within a Well Guarantee Area throughout the life of the mine (Kennecott, 2004). The company did many other things to protect the environment such as building a water treatment facility that purified 600 million gallons of water that was discharged into the Flambeau River throughout the life of the project, used high density polyethylene liners, leachate collection systems, backfilling the pit in the same geologic sequence and finally 
reclaiming the mine site to an environmentally stable condition with sustainable biodiversity (Kennecott, 2004). Wisconsin Law states that Flambeau Mining Company has to continue monitoring groundwater on and around the reclaimed mine site for 40 years following the state issuing the certificate of completion (Murphy, 2005). The Flambeau Mining Company submitted its notice of completion in 2001 and the WDNR has conditionally accepted the notice contingent upon the company's maintaining the vegetation performance of the backfilled pit. The WDNR accepted the notice effective November 19, 2001 and that began a four year period of monitoring during which the company is required to maintain the vegetative standards. Once the four year time period has expired (and the vegetative standards have been maintained) the WDNR can then inform the public of its intent to issue the Certificate of Completion (COC). After a public hearing and issuance by the state of the $\mathrm{COC}$ the reclamation bond is reduced from $\$ 11$ million dollars to $\$ 2.2$ million which is maintained for addition 20 years but the company's liability never ends. Flambeau Mining Company is no longer required to maintain the site vegetation but is required to continue to test the water after the state issues its Certificate of Completion (Murphy, 2005). Based on existing literature there were no incidences at this mine that significantly damaged or destroyed the environment that would require future generations to clean it up. The conclusion can be made that Kennecott in the Flambeau project has to date met the Acceptable Legacy criteria for sustainability and there are no indications that this will not be the case in the future.

\section{$\underline{\text { Full-Cost }}$}

In Green's report the Full-Cost criteria is defined as "minerals extracted, refined, and processed in such a way that the producer is responsible for mitigating, 
compensating, or offsetting the mine's known social and environmental costs" (Green, 2001, p. 35). This particular mine was owned by Kennecott Mining Company which is a wholly owned subsidiary of Rio Tinto plc which is one of the largest mining companies in the world. Therefore, the Flambeau Mining Company would have had the financial backing of Rio Tinto should anything have happened that they were not financially able to take care of. Kennecott had to issue a reclamation bond of $\$ 11.7$ million which is in place until the state issues the Certificate of Completion. As part of the Local Agreement that was signed in 1988 there was no refining or processing of the ore on site so Kennecott did not need to worry about that part of the criteria. The copper from Flambeau was shipped to Timmins, Ontario, for milling and metal recovery (Evans, 1996).

The general population of the town voiced their concerns when Kennecott originally applied for the permit back in the mid-1970's. When the company withdrew their permit application in 1977 it was due to concerns over the mine design (processing and refining of the ore on site) falling copper prices, and the anti-mining attitude. Based on those three factors when the company returned to reapply for permits in the late 1980's, Kennecott took the public concerns seriously and redesigned the project. Because of the size and economic scope of its parent company, Kennecott was financially viable and would not have abandoned the project or cause the local government to cleanup or fund the clean-up that could have been caused by the Flambeau project. While Rio Tinto is not legally liable for any accidents that Kennecott cannot cover, it is assumed that Rio Tinto would bear the financial burden due to their Environmental Policy as stated on their website "wherever possible we prevent, or otherwise minimize, mitigate 
and remediate, harmful effects of the Group's operations on the environment" (Rio Tinto, 2005). Each company is separate and liability does not automatically flow to the surviving companies. While it is not specifically stated, the reclamation bond is set up so that the most expensive scenario is covered and the company's liability never ends with regard to this site. In conclusion the Flambeau project adhered to the Full Cost criteria defined in Green's report. To date the company has met its obligations, and can be expected to do so in the future, but it cannot be predicated what will happen in the future.

\section{Contribution to Economic Development and Equity}

Two criteria for evaluation will be combined in this section of the analysis. They were combined because they are similar in definition and criteria for evaluation. The first criteria of contribution to economic development is defined as "the mine provides local and regional economic benefits that contribute to the long-term viability of the local and regional economies and facilitates a shift to sustainable economic activities" (Green, 2001, p. 36). The Equity criteria is defined as "benefits from proceeding with the mine are shared between those who develop the deposit, those who work at the mine, and those whose landscape and community are affected" (Green, 2001, p. 37).

The Local Agreement that was signed between Kennecott and the local units of government was a legally binding contract; the purpose of which was to "alleviate future mining impacts to the local area by establishing programs that would enhance the local economy and provide sustainable economic development to the local communities. The major provision in the Agreement designed for developing alternative economic activities was the direct tax payments to the local units of government guaranteed by Kennecott 
regardless of whether the mine made a profit" (NWRPC, 2005, p. 59) The main parts of the Local Agreement and Conditional Land Use Permit can be found in Appendix A.

Parts of this agreement that relate to the economic development and equity criteria are employment stipulations, that property values are guaranteed, the formation of a Local Mining Impact Committee, that local governments get first rights of refusal, that Flambeau will lease for $\$ 1.00$ two parcels of land, that the company will reimburse the local government up to $\$ 60,000$ for expenses incurred during negotiations, that for 25 years the company will hold harmless and pay 75 percent of any legal expenses incurred if the local units of governments are sued because of the mine, that the mining company will issue a certificate that a bond payable to the DNR has been secured and that they must annually certify they are in compliance and maintain the bond for 30 years after the mine closes, and finally that a minimum of $\$ 2.5$ million will be paid in local taxes regardless of copper prices. As can be seen there were a lot of economic stipulations in this local agreement to ensure that the community did not suffer any negative economic impacts from the mine.

In addition to the economic stipulations in the Local Agreement the Flambeau Mining Company had to comply with federal, state, and local taxes. Those taxes are Property Tax, State Franchise Tax, and Federal Income Tax and the money from those taxes did not directly come back to the local community. One tax specific to mining was the Net Proceeds Tax (NPT). This tax is in lieu of local property taxes on the value of the ore. This tax is only for metalliferous mining in Wisconsin and is to "provide compensation to the state and municipalities for the extraction of valuable, irreplaceable minerals and to compensate the state, counties, municipalities, and Native American 
communities for costs associated with the mining of these minerals"(NWRPC, 2005, p. 65). The tax is based on net proceeds (or profits) from the prior calendar year and the mining companies are required to file a return each year the mine is in operation. It is a progressive tax that begins at $3 \%$ and can increase to $15 \%$ and the tax brackets are indexed to the Gross National Product deflator (WDOR, 2005). Other fees are the Notice of Intent (NOI) fees and the Construction period payment. There is also interest earned on money within the Mining Investment and Local Impact Fund and there are federal distributions from sales, bonuses, royalties, and rental of federal lands (WDOR, 2005). When a company notifies the WDNR of its NOI they must pay an initial $\$ 50,000$ fee to pay the cost of negotiating a local agreement and pay another $\$ 50,000$ when the first fifty has been disbursed (WDOR, 2005). This continues until a maximum amount of $\$ 150,000$ has been paid. Once the Local Agreement is signed or if the company does not want to pursue a mining permit the state refunds the undistributed funds. It is also required for a company to pay a one time Construction Period payment of $\$ 100,000$ to each city, town, village, or Native American community with at least $15 \%$ of the ore body in their jurisdiction.

When the Flambeau Mining Company paid the NPT, construction fees, and Notice of Intent fees the money went into a Mining Investment and Local Impact Fund (MILIF). The MILIF earns interest as well. It is administered by a State appointed board that has a total of 11 members and has the authority to monitor the use of the payments to make sure they are managed effectively. The Board meets every two years or more depending on mining activity. The Governor appoints nine members that have staggered four year terms and the Secretary of Commerce and the Secretary of Revenue (or their 
designees) are ex officio members. Of the nine members that are appointed three are public members, two are county officials, two are municipal officials, one is a school board member, and one is a Native American.

This board distributes funds collected in the MILIF by making five types of payments (WDNR, 2005f). Throughout the entire life of the mine the Mining Impact Board makes annual first dollar payments of $\$ 100,000$ to each city, village, town, or county that contain at least $15 \%$ of the ore body (WDNR, 2005f). According to the WDNR “during some years the amount of net proceeds tax paid by the mining company could be insufficient to cover the entire amount of the required first dollar payments. In that case, the first dollar payments become the actual amounts available to each municipality from the mining company's tax payment. Simply stated, the amount of annual first dollar payments depend on the company's profitability, therefore, could range from zero to the maximum of $\$ 100,000 ”$ (WDNR, 2005f, p. 3). This specific scenario of the local municipalities tax payments being tied to profitability was planned for in the Local Agreement. The local units of governments included a supplemental first dollar payment for when Flambeau could not cover the full first dollar payment, and a supplemental additional payment to Rusk County for when the additional payment to Rusk County is below the required $\$ 250,000$ (NWRPC, 2005). In the following table it is shown the types of payments, frequency, funding source, and dollar amounts. This table does not include information on the supplemental payments because that is exclusive to the Flambeau Mine and not required by Wisconsin law. 
TABLE 3: Types of Payments to Municipalities

\begin{tabular}{|l|l|l|l|l|}
\hline Payment Type & Recipient & Frequency & Fund Source & Dollar Amount \\
\hline $\begin{array}{l}\text { Cost of Local } \\
\text { Agreement } \\
\text { Negotiations }\end{array}$ & $\begin{array}{l}\text { Municipalities } \\
\text { Negotiating local } \\
\text { agreements }\end{array}$ & $\begin{array}{l}\text { By Grant, during } \\
\text { negotiations }\end{array}$ & $\begin{array}{l}\text { Mining } \\
\text { company, with } \\
\text { Notification of } \\
\text { Intent }\end{array}$ & $\begin{array}{l}\text { Up to \$150,000 } \\
\text { in aggregate }\end{array}$ \\
\hline Construction & $\begin{array}{l}\text { Municipalities } \\
\text { containing ore } \\
\text { body; Tribes }\end{array}$ & One Payment & Mining company & $\begin{array}{l}\text { \$100,000 (not } \\
\text { indexed) }\end{array}$ \\
\hline First Dollar & Same As Above & $\begin{array}{l}\text { Annually during } \\
\text { operations }\end{array}$ & Net proceeds tax & $\begin{array}{l}\text { \$100,000 } \\
\text { indexed) }\end{array}$ \\
\hline $\begin{array}{l}\text { Additional } \\
\text { Payments }\end{array}$ & Counties & $\begin{array}{l}\text { Annually during } \\
\text { operations }\end{array}$ & Net proceeds tax & $\begin{array}{l}\text { Up to } \$ 250,000 \\
\text { indexed) }\end{array}$ \\
\hline $\begin{array}{l}\text { Discretionary } \\
\text { Payments }\end{array}$ & Municipalities & Based on need & Net proceeds tax & Various \\
\hline
\end{tabular}

Source: WDNR, 2005f

The first dollar payments for counties must be used for mining related purposes but other municipalities have no such requirement. Counties are also eligible for mandatory additional annual payments from the Fund. This amount could be $20 \%$ of the tax collected or $\$ 250,000$ whichever is less. This money must be used for mining related purposes and is not guaranteed but depends on the availability of NPT (WDNR, 2005f). The Board can also make discretionary payments to help mitigate the impacts of current mining or past metallic mining. These are grants the municipalities can apply for.

In terms of the Flambeau Mine the company paid over \$14 million dollars in NPT to the State of Wisconsin throughout the life of the mine. Of that money approximately $\$ 8.6$ million went into the MILIF and \$5.5 million went into the Badger Fund. The Badger Fund is the general fund for the state and the money in that fund could be used for state government purposes (NWRPC, 2005). The MILIF receives $60 \%$ of the total amount of NPT or enough money to make full first dollar payments, whichever is greater. The Badger fund then gets the other $40 \%$ of the NPT, which totaled $\$ 5.5$ million. 
Of the $\$ 8.6$ million that went into the MILIF about $\$ 8.4$ million came back to the local units of government in the form of construction year payments, first dollar payments, and additional payments to the County as well as discretionary grants. The other \$200,000 was transferred to the Wisconsin Department of Commerce and given out as grants to help convert the mining buildings to alternative uses. The $\$ 5.5$ million that went into the Badger Fund was eventually put into the states general fund and used for government purposes.

Table 4 gives a summary of the amount of money that went to each local governmental unit based on the Net Proceeds Tax and Local Agreement payments. In each payment type there is a description of where the funds came from. When it is labeled 'State' it is from the Mining Investment and Local Impact Fund (MILIF) and when it is labeled 'Flambeau' it is the supplemental first dollar payments and supplemental additional payments to Rusk County. The amounts are for the entire mine life. 


\begin{tabular}{|c|c|}
\hline \multicolumn{2}{|c|}{ Rusk County } \\
\hline Construction Payment - State & $\$ 100,000$ \\
\hline First Dollar Payments - State & $\$ 608,000$ \\
\hline County Additional Pymts. - State & $\$ 933,000$ \\
\hline Supplemental Payments - Flambeau & $\$ 1,865,000$ \\
\hline Total for Rusk County & $\$ 3,506,000$ \\
\hline \multicolumn{2}{|c|}{ City of Ladysmith } \\
\hline Construction Payment - State & $\$ 100,000$ \\
\hline First Dollar Payments - State & $\$ 608,000$ \\
\hline Supplemental Payments - Flambeau & $\$ 413,000$ \\
\hline Total for City of Ladysmith & $\$ 1,121,000$ \\
\hline \multicolumn{2}{|c|}{ Town of Grant } \\
\hline Construction Payment - State & $\$ 100,000$ \\
\hline First Dollar Payments - State & $\$ 608,000$ \\
\hline Supplemental Payments - Flambeau & $\$ 413,000$ \\
\hline Total for Town of Grant & $\$ 1,121,000$ \\
\hline $\begin{array}{l}\text { GRAND TOTAL OF MONEY } \\
\text { RECEIVED TO LOCAL } \\
\text { MUNCIPALITIES } \\
\end{array}$ & $\$ 5,748,000$ \\
\hline
\end{tabular}

Sources: WI Dept. of Revenue, Rusk Co. Auditor, C. of Ladysmith

Taken from: Northwest Regional Planning Commission, 2005

In addition to the regular payments from the MILIF the Local Agreement stipulated that Kennecott had to pay a minimum of $\$ 2.5$ million in supplemental payments to the three local government units but as can be seen from the above chart they paid roughly $\$ 2.7$ million. This money was in excess to the Net Proceeds Tax and therefore was not restricted in what it could be spent on.

In addition to those supplemental payments, there were also discretionary grants that the local government units could apply for. The money for these grants came from the MILIF and it paid out around \$5.7 million additional dollars between 1995 and 1998 . Each local unit of government (Rusk County, City of Ladysmith, Town of Grant) applied 
for and received a discretionary grant at least once if not three or four times (Table 4 shows the amount of money in grants). It should be noted that the three local units of government have received approximately $\$ 11$ million dollars either directly or indirectly from the Flambeau Mining Company (NWRPC, 2005).

The money that governments received was used for many different purposes. Rusk County used their construction year payment to not only cover the fiscal impacts associated with the construction of the mine but to "include the renovation of a vacant

\begin{tabular}{|lr|}
\hline \multicolumn{2}{|c|}{ Table 5 Total Discretionary Grants } \\
\hline \multicolumn{1}{|c|}{ Recipients } & \multicolumn{1}{c|}{ Amount } \\
\hline C. Ladysmith \& Rusk Co. & $\$ 4,430,430$ \\
\hline C. Ladysmith, T. Grant, \& Rusk Co. & $\$ 750,000$ \\
\hline C. Ladysmith \& LCIDC & $\$ 380,000$ \\
\hline C. of Ladysmith & $\$ 24,000$ \\
\hline Rusk County & $\$ 100,000$ \\
\hline Total & $\$ 5,684,430$ \\
\hline Source: Wisconsin Department of Revenue \\
\hline $\begin{array}{l}\text { From: Northwest Regional Planning } \\
\text { Commission Report, 2005 }\end{array}$
\end{tabular}
industrial building, which would be leased to growing companies that would provide jobs in the future, and the preparation of an economic development plan that would identify mining-related concerns and provide a framework for long-term future economic development" (NWRPC, 2005, p. 74). The first dollar payments, supplemental payments and discretionary payment grants were used by the local communities to fund and invest in a number of different projects. The hope was that these projects would lead to economic development.

An example is the Glen Flora Building which was expanded at a cost of $\$ 300,000$ for a computer recycling firm called 5R Processors. When they moved in they had 10 employees and after the expansion they now have 45. Also half the money needed for a remodeling of the Fritz Avenue Manufacturing Plant was from the first dollar payment and supplemental payments (NWRPC, 2005). Two of the three tenant spaces are filled 
and there are about 15 people employed between the two firms. The Rusk County Airport's runway was expanded in 1998. The project totaled \$3 million dollars and approximately $\$ 600,000$ of that came from mining and the rest from the Wisconsin Department of Transportation (NWRPC, 2005). A new terminal, maintenance and hanger building were built and an access road paved. The project cost $\$ 525,680$ all of which came from the mining fund. The list of areas where mining funds contributed to economic diversification is long. In total there were 17 different projects that were funded with money either directly or indirectly from Flambeau Mine. A summary of each project is included in Table 6.

There were also four projects that were not necessarily funded directly from the mine but were started because the economy was stronger due to the mining funds. This included building 36 apartments, the opening of a $\$ 6$ million grocery store, opening two new convenience stores and a bank, and a new General Motors dealership opened.

Also Flambeau Mining Company made many charitable contributions to the local community. The best example of that was with the Rusk County Community library. During 1994 Flambeau Mining Company wanted to partially fund a major project in the area that would serve the greatest segment of the community. The company chose the library because the one that was in current use was very old (built in 1907) and was not in compliance with the Americans with Disability Act (ADA). The land the library was on was not big enough to allow expansion and the cost of retrofitting the building to be in compliance with the ADA would have cost about 


\begin{tabular}{|c|c|c|c|c|c|c|}
\hline \# & $\begin{array}{l}\text { Building or Project } \\
\text { Name }\end{array}$ & Cost (dollars) & Funded From & Current Use & $\begin{array}{l}\text { Company Name } \\
\text { in Building }\end{array}$ & $\begin{array}{l}\text { Number of } \\
\text { Employee's }\end{array}$ \\
\hline & $\begin{array}{l}\text { Glen Flora Satellite } \\
\text { Building }\end{array}$ & 300,000 & $\begin{array}{l}\text { 1st dollar and supplemental } \\
\text { payments (Rusk County) }\end{array}$ & $\begin{array}{l}\text { Computer Recycling } \\
\text { and salvage }\end{array}$ & 5R Processors & 45 \\
\hline 2 & $\begin{array}{l}\text { Fritz Avenue } \\
\text { Manufacturing Plant } \\
\text { (reuse) }\end{array}$ & 900,000 & $\begin{array}{l}\$ 450,000 \text { from 1st dollar } \\
\text { and supplemental } \\
\text { payments (County and } \\
\text { City) }\end{array}$ & $\begin{array}{l}2 \text { of } 3 \text { tenant spaces } \\
\text { leased by textbook } \\
\text { printer and sign printer }\end{array}$ & & 15 \\
\hline & $\begin{array}{l}\text { Weyerhaeuser Satellite } \\
\text { Building }\end{array}$ & 300,000 & $\begin{array}{l}1 \text { st dollar and supplemental } \\
\text { payments (Rusk County) }\end{array}$ & $\begin{array}{l}\text { Originally leased by a } \\
\text { medical supply firm }\end{array}$ & & 3 \\
\hline 4 & $\begin{array}{l}\text { Ladysmith/Rusk County } \\
\text { Enterprise Center }\end{array}$ & $1,400,000$ & $\begin{array}{l}\$ 560,000 \text { from 1st dollar } \\
\text { payments and } \\
\text { supplemental payments } \\
\text { (City and County) }\end{array}$ & $\begin{array}{l}4 \text { of } 6 \text { offices and all } 7 \\
\text { manufacturing spaces } \\
\text { are occupied }\end{array}$ & & 20 \\
\hline & \begin{tabular}{|l|} 
Rusk County Airport \\
Runway Extension \\
Project
\end{tabular} & $3,000,000$ & $\begin{array}{l}\$ 600,000 \text { from } 1 \text { st dollar } \\
\text { and supplemental payment } \\
\text { (County) }\end{array}$ & $\begin{array}{l}\text { airport runway was } \\
\text { lengthened }\end{array}$ & & \\
\hline 6 & $\begin{array}{l}\text { Rusk County Airport } \\
\text { Terminal Project }\end{array}$ & 525,680 & $\begin{array}{l}\$ 473,100 \text { from mining } \\
\text { Discretionary Payments } \\
\text { Program (Rusk County) } \\
\text { and } \$ 52,580 \text { from } 1 \text { st dollar } \\
\text { and supplemental } \\
0 \text { payments (Rusk County) }\end{array}$ & $\begin{array}{l}\text { new airport terminal, } \\
\text { maintenance and } \\
\text { hangar building, and } \\
\text { paved access road }\end{array}$ & & \\
\hline 7 & $\begin{array}{l}\text { Acrylic Design } \\
\text { Fabricators Building } \\
\text { Project }\end{array}$ & $1,050,000$ & $\begin{array}{l}\$ 585,900 \text { mining } \\
\text { Discretionary Payments } \\
\text { Program (City and County) } \\
\text { and } \$ 400,000 \text { from } 1 \mathrm{st} \\
\text { dollar and supplemental } \\
\text { (City and County) }\end{array}$ & $\begin{array}{l}2 \text { companies are } \\
\text { located in the building at } \\
\text { present time }\end{array}$ & $\begin{array}{l}\text { Acrylic Design } \\
\text { Fabricators, Inc }\end{array}$ & 40 \\
\hline 8 & $\begin{array}{l}\text { Rusk County Forest } \\
\text { Industry Business Park } \\
\text { Project }\end{array}$ & $1,250,000$ & $\begin{array}{l}\$ 479,430 \text { mining } \\
\text { Discretionary Payments } \\
\text { Program and } \$ 53,270 \text { from } \\
1 \text { st dollar and supplemental } \\
\text { payments (both from City } \\
\text { and County) }\end{array}$ & \begin{tabular}{|l|} 
\\
project involved \\
developing 110 acres \\
industrial site and \\
20,000 sq. $\mathrm{ft}$ warehouse \\
\end{tabular} & & $\begin{array}{l}70 \text { jobs are } \\
\text { expected to } \\
\text { be created }\end{array}$ \\
\hline 9 & $\begin{array}{l}\text { Westlake Enterprises } \\
\text { Relocation Project }\end{array}$ & 275,000 & $\begin{array}{l}\$ 125,000 \text { from 1st dollar } \\
\text { and supplemental } \\
\text { payments (County) }\end{array}$ & \begin{tabular}{|l|} 
Meadowbrook Center \\
was renovated and \\
6,000 sq. ft. were added
\end{tabular} & $\begin{array}{l}\text { Occupied by a } \\
\text { service orientated } \\
\text { operation }\end{array}$ & $\begin{array}{l}\text { average } \\
\text { number of } \\
\text { jobs is } 45\end{array}$ \\
\hline 10 & $\begin{array}{l}\text { Meadowbrook Center } \\
\text { Addition }\end{array}$ & 880,000 & $\begin{array}{l}\$ 380,000 \text { from } \\
\text { Discretionary Payment } \\
\text { Program }\end{array}$ & \begin{tabular}{|l|} 
Pre-leased and the \\
company invested at \\
least $\$ 1.25$ million in \\
new fixtures and \\
equipment
\end{tabular} & \begin{tabular}{|l} 
Rockwell \\
Automation
\end{tabular} & 50 \\
\hline 11 & $\begin{array}{l}\text { Conwed Designscape } \\
\text { Relocation Project }\end{array}$ & $2,872,000$ & $\begin{array}{l}\text { all from mining } \\
\text { discretionary payments } \\
\text { (City and County) }\end{array}$ & $\begin{array}{l}\text { Conwed Designscape } \\
\text { was moved into a } \\
\text { modern facility in } \\
\text { Ladysmith Industrial } \\
\text { Park }\end{array}$ & \begin{tabular}{|l} 
Conwed \\
Designscape \\
(furniture \\
manufacturer)
\end{tabular} & 125 \\
\hline 12 & $\begin{array}{l}\text { Weather Shield } \\
\text { Expansion Project }\end{array}$ & outgrowth from & $\mathrm{n}$ preceding project. Used ol & d Conwed building. & & \begin{tabular}{|l|} 
created \\
many jobs
\end{tabular} \\
\hline 13 & $\begin{array}{l}\text { Norse Building Systems } \\
\text { project }\end{array}$ & $2,200,000$ & $\begin{array}{l}\$ 750,000 \text { Discretionary } \\
\text { Payments (County, City, } \\
\text { Town of Grant) and } \\
\$ 300,0001 \text { st dollar } \\
\text { payments (County and } \\
0 \text { Town of Grant) }\end{array}$ & $\begin{array}{l}\text { Builds manufactured } \\
\text { homes and closed wall } \\
\text { panels }\end{array}$ & Norse & 70 \\
\hline 14 & $\begin{array}{l}\text { Rusk County Visitor } \\
\text { Center and Rail } \\
\text { Museum }\end{array}$ & 200,000 & $\begin{array}{l}\text { combination of state } \\
\text { budget, } 1 \text { st dollar and } \\
\text { supplemental payments } \\
\text { (County), and borrowing by } \\
\text { Ladysmith }\end{array}$ & $\begin{array}{l}\text { Built a new visitor } \\
\text { center which is larger } \\
\text { and handicap } \\
\text { accessible }\end{array}$ & & \\
\hline 15 & Nielson Ford Project & $1,815,000$ & $\begin{array}{l}\text { Building was originally a } \\
\text { car dealership that was } \\
\text { turned into a Northern } \\
\text { States Power (NSP) line } \\
\text { maintenance building. It } \\
\text { was converted back into a } \\
\text { dealership with no mining } \\
\text { money used }\end{array}$ & $\begin{array}{l}\text { Car dealership closed in } \\
2001 \text { but currently a } \\
\text { physical rehabilitation } \\
\text { clinic. }\end{array}$ & & \\
\hline 16 & $\begin{array}{l}\text { Flambeau Mine } \\
\text { Buildings Conversion } \\
\text { Projects }\end{array}$ & $\begin{array}{l}\text { Flambeau } \\
\text { Mine is } \\
\text { leasing the } \\
\text { use of their } \\
\text { administration } \\
\text { building, and } \\
\text { water } \\
\text { treatment } \\
\text { facility. }\end{array}$ & $\begin{array}{l}\$ 100,000 \text { grant from } \\
\text { Department of Commerce } \\
\text { Mining Program and } \\
\$ 370,000 \text { in borrowed } \\
\text { funds to convert } \\
\text { administration building to a } \\
\text { DNR service center } \\
\text { (completed in } 1999 \text { ). }\end{array}$ & $\begin{array}{l}\text { Wisconsin Department } \\
\text { of Natural Resources- } \\
\text { Service Center }\end{array}$ & WDNR & 12 \\
\hline & $\begin{array}{l}\text { Former water treatment } \\
\text { facility for mine }\end{array}$ & & $\begin{array}{l}\text { West half ( } 2,889 \text { sq. } \mathrm{ft}) \text { was } \\
\text { turned into a maintenance } \\
\text { garage for WDNR. East } \\
\text { half }(4,320 \text { sq. } \mathrm{ft}) \text { was } \\
\text { turned into a garage and } \\
\text { headquarters for local line } \\
\text { maintenance for Xcel } \\
\text { Energy. }\end{array}$ & $\begin{array}{l}\text { WDNR also built a third } \\
\text { building }(7,320 \text { sq. } \mathrm{ft}) \\
\text { on property. Its use is } \\
\text { for DNR vehicle } \\
\text { storage. City financed } \\
\text { the project and loaned it } \\
\text { to LCIDC for } \$ 318,000 \\
\text { and the DNR subleases } \\
\text { the building from LCIDC }\end{array}$ & & \\
\hline Sour & rce: Northwest Regional & sor & nission, 2005 & & & \\
\hline
\end{tabular}


$\$ 200,000$. It was determined a new library should be built and the Flambeau Mining Company joined Rusk County, the City of Ladysmith, and other businesses and individuals in the area to raise money for this project. The company pledged $\$ 500,000$ to build the $\$ 1.4$ million dollar library. It has a 9,000 square foot library on the second level and a 9,000 square foot lower level that is for community/meeting rooms. It is located in a park on the shores of Corbett Lake so it is in a picturesque setting. Besides the library contribution, the Flambeau Mining Company provided scholarships for children of employees starting in 1994, and in 1998 started to provide scholarships to high school students in the area. There are four grants that are awarded at $\$ 500$ each. This program will continue for another 20 years (NWRPC, 2005). While the mine was open (19931997) the company also had an intern training program that hired summer interns who were children of current employees or were recruited through a university recruiting program. Eighteen interns were hired and 4 were children of employees and 12 were from the local area. They also made educational donations to local schools, allowed field trips on the site, and created a Flambeau Mine visitor center. Even when the mine closed and they began reclamation, the Flambeau Mining Company continued their charitable donations. Not all of Flambeau's charitable contributions have been mentioned due to how many there were. All uses of the money have not been noted, but the major allocations were described above.

While a community receiving $\$ 11$ million dollars in the span of approximately 4 years is impressive, the community is no longer receiving money from MILIF since no mining is being done. The community relations plan for 2005-2009 deals with keeping the local community informed of the mines reclamation and groundwater monitoring as 
well as helping the Ladysmith Community Industrial Development Corporation (LCIDC) develop property owned by Flambeau. It can be concluded that the Flambeau Mining Company has helped the area economically in the short term. However without analysis in the future it cannot be determined whether long term sustainability has been achieved. It has to be noted that any business that closes stops contributing to the local economy but yet for a mining company to operate it must adhere to something that no other business has to.

\section{$\underline{\text { Consent }}$}

This particular criteria is defined as "the informed and voluntary consent of indigenous people and local communities who are most affected by the burdens imposed by the proposed mine is secured before the mine proceeds" (Green, 2001, p. 37). When the mine was first being permitted in the 1970's there was a negative attitude with regard to mining. Before the Agreement was made the community did not want the mine to be developed. It was a very contentious issue and it was surprising that the two sides could sign a legally binding document. Once it was signed it went to the local governments to be ratified. Rusk County's Board approved it by 14-4, the Town of Grant Board approved it by 3-0 and the Ladysmith City Council approved it 6-1 (NWRPC, 2005). After the Local Agreement was signed in 1988 Kennecott started to complete the EIR and obtain the necessary mining permits. Kennecott's steps to work with the community and to develop the Local Agreement helped the community members to know that their needs and concerns were being addressed. Such an Agreement has not been instituted at any other mine. It is the first of its kind. The company also took steps to inform the public of the project by having a visitor's center and offering tours of the facilities. As part of the 
mine permitting, there were many public hearings and discussions about the company's permit application so the public had many opportunities to voice their concerns. The Northwest Regional Planning Commission (NWRPC) conducted a survey of businesses and the general public in 2004. The survey questions and results can be found in Appendix B. The results showed that the majority of respondents felt that the mine was a positive thing for the community. Also the business results were that a majority of the businesses were around before the mine opened and they are around since the mine has been reclaimed. Conversely it shows that the mine did not have a positive effect on local business in the area because the survey asked if the businesses were expecting business from the Flambeau Mine and 43 respondents said no and 35 said yes. Also the survey asked if the businesses expected Flambeau Mines contractors or subcontractors to purchase goods from them and again 44 said no and 35 said yes. When asked if the presence of the Flambeau Mine benefited your business 10 said significantly, 42 said somewhat, 24 said not at all, and 4 did not know. Finally the survey asked if after the Flambeau Mine completed reclamation has your company had to permanently reduce its employee size, and the answers were 7 yes and 70 no. These responses show that the mine did not have a negative impact on local business and may have benefited at least several. The importance of the Flambeau Mine was that it changed the public's perception of mining. When the mine was first permitted and the Local Agreement was signed the public did not want a mine but after the mine was reclaimed the public had a positive opinion of Kennecott. In the survey given to residents the question was asked if another deposit was found would the community welcome Flambeau Mining Company back to mine it and 285 respondents said yes and 94 said no. Green's definition of the 
consent criteria was met even prior to the mine opening in the signing of the Local Agreement and was also earned through the business practices of the company during and after the mines operation as indicated in the surveys.

Respect for Ecological Limits, Maintenance of Ecological Integrity and Landscape $\underline{\text { Requirements and Offsetting Restoration }}$

These two criteria are combined because they cover the same topic. The first criteria of respect for ecological limits etc. is defined as "the mine does not result in impairment of ecosystem processes, or result in significant loss of ecosystem goods or ecosystem services, either at local, regional or global scales" (Green, 2001, p. 37). The offsetting restoration criteria is defined as "the mine operator goes beyond ensuring that the new mine site will be reclaimed and restored to regulatory requirements and best practices" (Green, 2001, p. 38).

The site was mostly forest land, old fields, and active farming areas (WDNR, 1990) before mining commenced. The Local Agreement had sections in it devoted to reclamation and monitoring of the reclaimed site and length of responsibility. In this particular case Kennecott sequentially backfilled the pit with the same rock and soil they took out. After they backfilled they contoured it as before and constructed wetlands and did seeding and planting. In 1999 they added four miles of recreational hiking trails and are continuing to monitor the vegetation that was planted. They are still working on being in compliance with the Agreement and have not had any violations with regard to their 11 permits and 200 conditions requiring additional monitoring and operational safeguards (NWRPC, 2005). The site is now an area with many hiking trails and just recently an area where people can ride their horses. The company also organized a 
Community Advisory Group whose purpose is to advise Kennecott Minerals Company in land management and use (Murphy, 2005).

As was stated previously the site was not used for public activities. It was reclaimed as prairie, wetlands, and woodlands. Now the land is used by the general population as it includes a 4 mile nature hiking trail. It can be said that even though the site is different than it was before the state would not have issued the reclamation permits if there were going to be major impacts on the environment. It can be concluded that overall the Flambeau Mining Company conducted a sustainable project with regard to these final two criteria.

\section{$\underline{\text { Summary Conclusions }}$}

There were three parts to the framework that went into analyzing the Flambeau Mine. The first part dealt with the company being proactive in communicating with the local community and conducting an in-depth analysis of the project. The Flambeau Mining Company was sustainable with regard to both of these requirements. The second part dealt with making sure the community develops in ways that are consistent with their own vision. This was analyzed in the consent criteria. The results of both of the surveys which are found in Appendix B of this report were also considered. The Flambeau Mine was sustainable with regard to the second part of the framework. Finally the third part was analyzing the nine sustainability criteria. The first of those criteria was the NeedPresent Generation and yes it was considered sustainable because the copper from the mine was needed by society. The second criteria was Future Need and this was also considered sustainable because mining this particular deposit did not adversely affect future generations from meeting their copper needs. The third criterion was Acceptable 
Legacy and it was to date considered sustainable. Full-Cost was the fourth criteria and again it is to date considered sustainable but one never knows what the future holds. The fifth and sixth criteria were combined (Contribution to Economic Development and Equity) in the analysis and it was concluded that yes the Flambeau Mine helped the community in the short term but not enough time has elapsed to determine long-term sustainability. The seventh criterion of Consent was met and additionally the public's perception of mining was probably improved because of this project. The final two criteria were combined (Respect for Ecological Limits, Maintenance of Ecological Integrity and Landscape Requirements and Offsetting Restoration) and it is concluded that Flambeau Mining Company conducted a sustainable project. 


\section{CHAPTER 5}

\section{Comparisons}

The experience of the successful Flambeau Mining project will be compared against the experience of the Crandon deposit. The Flambeau deposit was first discovered in 1968 and the Crandon deposit was discovered in 1975. The Crandon deposit was also sulfide generating and the company was planning to mine zinc and copper. In the early 1980's Exxon Minerals Company submitted all necessary permit applications for the Crandon Mine and in November 1986 the WDNR published its Final Environmental Impact Statement (WDNR, 2005I). The company withdrew their permit application in December 1986, citing falling copper prices. The deposit was thought to have 55 million tons of ore and would be an underground mine. Its dimensions are approximately 4,900 feet long, 2,200 feet deep and 100 feet wide. The total surface area that would be disturbed by mine development would have been approximately 550 acres (WDNR, 2005I). It should be noted that the Flambeau Mine disturbed only 181 acres and was only 220 feet deep. The total mine life of the Crandon was projected to be 34 years which included construction, operation, and reclamation.

During the life of the Crandon project there were four different owners. When the deposit was first discovered Exxon owned the property and when they renewed interest in mining the deposit in 1994 it was a partnership between Exxon and Rio Algom, Ltd. They submitted an NOI which resulted in a public hearing. In January 1998 Rio Algom bought out Exxon's interest in the project and renamed the company Nicolet Mineral Company (NMC). In 2000 it was announced that Billiton, Plc. had 
bought out Rio Algom and a year later Billiton merged with BHP (Broken Hill Proprietary) to form BHP Billiton. It was in 2002 that BHP Billiton announced that they were putting the Crandon project up for sale and were closing the NMC's office in Crandon. In April 2003 NMC was bought by Northern Resource Group, LLC which is a local logging company. Northern Resource group then said that they would not withdraw their permit application. On October 28, 2003 the Mole Lake Sokaogon Chippewa and Forest County Potawatomi purchased the Nicolet Minerals Company and the land associated with the project site for $\$ 16.5$ million. They then sent a letter to the WDNR formally withdrawing the permit application.

It is interesting to note that the deposits were discovered within 13 years of one another but one was able to get the necessary permits and the other was not. When Exxon started the permitting process again in 1994, the Flambeau Mine was already operating and one would think that would help. However, in 1994 there was still a lot of negative opinion about sulfide mining. The Crandon deposit is much larger than the Flambeau and the mine life would have been considerably longer. It is a very deep deposit that would not be able to be mined as an open pit. Other differences were that the proposed Crandon mine planned to dredge and fill wetlands which necessitated a permit from the United States Army Corps of Engineers (USACE). The USACE completed a preliminary Environmental Impact Statement about the project (Evans, 1998). Therefore the federal government became involved in the Crandon Mine project which was not the case in the Flambeau project. The federal government also became involved because of the Crandon's proximity to Indian reservations. Because of the trust responsibility related to Native Americans, 
the United States Environmental Protection Agency had regulatory authority to protect federal waters.

At the time the permit application was withdrawn NMC had signed Local Agreements with the towns of Nashville, and Lincoln, the City of Crandon, and Forest County (Evans, 1998). However, some segments of the community still did not want the mining project and they organized to defeat it. In 1998 the Governor of the state signed 1997 Act 171: Mining Moratorium Law, which requires a mining company to submit examples of mines that have been closed for 10 years without pollution to the groundwater or surface water and required them to submit an example mine that has operated for 10 years without pollution to groundwater or surface waters (WDNR, 2005j). NMC submitted the required examples and in 2003 the WDNR was analyzing their example sites to see if they met the requirements. This was not a requirement when the Flambeau was applying for their permits.

When comparing these two projects the Flambeau Mine was discovered in 1968 and Kennecott tried to permit it in 1976 which was the same year the Crandon deposit was discovered. Kennecott Minerals then came back in 1986 with a scaled back project without processing on site and an open pit rather than an underground mine. While researching the proposed Crandon Mine there was no mention of Exxon Minerals redesigning their proposed mine when they came back to try to permit it in 1994. It is interesting to note that in 1986 when Exxon cited falling copper prices Kennecott renewed their project. Exxon could have followed Kennecott's lead and made Local Agreements with the communities prior to their submittal of the EIR as 
well as potentially scaling back the project. Instead they put the whole project on hold, which contributed to its final demise.

Other differences in these two deposits was that the Crandon project had multiple owners whereas Kennecott was the only company that owned the Flambeau deposit, which helped the community build a level of trust with the company. Another important factor is that with Crandon there were federal permits that needed to be approved and that the mine was going to impact two Indian tribes. With regard to Local Agreements, Kennecott Minerals signed their Local Agreement before they submitted their Environmental Impact Report. There was no mention of timing of the Local Agreements with regard to Crandon Mine. It was stated in Evans 1998 that NMC had signed Local Agreements with the towns surrounding the proposed mine but NMC would have been the second owner. Another minor effect on the project would have been the Mining Moratorium Law. Flambeau would not have had to submit examples of successful mining. This probably affected the Crandon project but at the time of their permit withdrawal, NMC had submitted the necessary examples. It would have been a minor inconvenience but for a profitable mine a company would have to follow through.

As can be seen, differences existed between the Flambeau Mine and the proposed Crandon Mine. These included the anticipated the size and scope of the operation, length of operation, differences in mining methods, changes in ownership of the Crandon resulting in ownership by two Indian tribes, differing state requirements, and differing federal jurisdiction. It appeared that there was more public sentiment against the Crandon operation than with the Flambeau Mine. This 
difference could be attributed to the location of the proposed Crandon project near to two Indian reservations. According to many articles the people on those reservations depend on part of their food source from the rivers and lakes near the project.

\section{$\underline{\text { Sustainability and other Businesses }}$}

The Flambeau Mining Project can be compared against other business projects in Ladysmith with regard to local zoning requirements. Every new business in Rusk County must obtain a Conditional Use permit. The permit costs $\$ 325$ dollars and the applicant must go before the zoning committee that will look at local concerns. This is the only requirement for businesses that cannot potentially effect the environment. The reason why the mine had to get so many permits is because of its impact on the environment and local concerns. As can be seen it is much more difficult to develop a mining operation than to establish another type of business. Additionally public perception of mining is more negative than that toward other business endeavors, in spite of the fact that the community appears to experience greater benefit from the mine than from another businesses. If the mining industry is held to a higher standard and they succeed in meeting it, the publics' perception of the industry may change.

The interesting part of this project is that because of the environmental implications of mining everything that a mine could affect is analyzed. Any other business would not have had to sign a Local Agreement with the community it wanted to operate in. If Wal-Mart or another large store would want to open in Ladysmith it would probably be welcomed with open arms. But yet if that particular business closed, it would have a negative economic impact. There would have been no guarantees to help protect the local community from boom-bust cycles, like there 
was in regard to the Flambeau Mine. Sustainability should not only be viewed in terms of the environment but a company's economic impact on the local community. There are many projects that are started and then end suddenly but yet they are not viewed with such negativity as mining. In the case of the Flambeau Mine, Kennecott helped the local community and now those residents would be willing to have another mine operated by Flambeau in their community. The Flambeau Mine was a significant factor in changing the public's perception of mining. The three part framework introduced in this thesis should not only be used to analyze current or reclaimed mining projects but any project that could affect the local community. 


\section{CHAPTER 6}

\section{Conclusion}

A three part framework described in the analysis section was used to determine whether the Flambeau Mine can be considered a sustainable project. The first part dealt with whether the company completed an in-depth local and regional analysis and communicated with the local community. The second part was to determine whether the project helped the community to develop within its own vision (MMSD, 2005). The third part of the framework used Green's nine criteria for sustainability.

After analyzing the evidence relative to completion of a local and regional analysis and communication with the local community it was determined that the company was communicating effectively with the local community in terms of following WDNR regulations and/or laws. It was shown that even if it wasn't required to make a Local Agreement with the local units of government Kennecott negotiated such an agreement that was subsequently overwhelmingly passed by the local governments.

The second part of the framework analyzed the whole project to determine if it was developed in a way that was consistent with the communities own vision. This was analyzed using the response to the survey that was conducted by the Northwest Regional Planning Commission. Overall, there was positive feedback from the community members about this project.

The Flambeau Mine was evaluated using each of Green's nine criteria for determining sustainability. With regard to the first criteria Need-Present Generation 
it was determined that enough information does not exist to determine the contribution to human well being. It was determined that the mineral in question did contribute to the current needs of our society and that the minerals produced were required in the short to medium term. Relative to future need the Flambeau Mine was sustainable. Kennecott in the Flambeau project is currently meeting the acceptable legacy criteria for sustainability. From the analysis it was determined that the Flambeau project is currently adhering to the full cost criteria. Relative to the contribution to economic development and equity, it can be concluded that the Flambeau Mine helped the area economically in the short term but it cannot be evaluated with regard to its long-term impact. If the mine is analyzed again in the future, the long term aspects of this criterion could be determined. According to Green's definition of the consent criteria, it was determined that it was met prior to the mine opening and because of the project the public's perception of mining was changed in Ladysmith. The Flambeau Mine was shown to be sustainable with regard to the final two criteria of Respect for Ecological Limits, Maintenance of Ecological Integrity, Landscape Requirements and Offsetting Restoration.

Overall it can be concluded that the Flambeau Mine was a sustainable project. It was shown that in the short term there were many benefits for the communities surrounding the mine, but it can't be shown that the benefits will continue long past the mines closure.

It can be questioned whether the Local Agreement sacrificed long term sustainability for short term interests. Because the Local Agreement had many specific conditions it may have deterred the community from receiving greater 
economic benefits. For instance if the mine had been allowed to have processing facilities on-site, and to have the pit deeper than 225 feet the mine would have lasted longer than four years and therefore providing more economic benefits to the community. These stipulations in the Local Agreement could therefore have hindered the community from achieving greater long-term economic benefits. The topic of the Flambeau Mine's contribution to sustainability should be revisited 10 or more years after reclamation.

\section{$\underline{\text { Recommendations }}$}

The Kennecott Minerals Company is planning to develop the Eagle deposit outside of Marquette Michigan. It is interesting to see the beginning of the project and how the company is relating to the local communities. They have ads on the television detailing the project and what they are doing to protect the environment as well as providing the example of the Flambeau Mine. Also Kennecott has participated, along with other parties (i.e. local community members, MDEQ, scientific experts, KBIC representatives, etc.), to help write the Metallic Mining Law for the state of Michigan which was signed by Governor Granholm last year. That same group is now writing the rules that the MDEQ will use to administer this new law. Kennecott has also organized meetings for local community members to hear updates on the project and has answered questions about their mining practices. Based on the first part of the sustainability framework, Kennecott is being proactive communicating with the community with regard to the Eagle Project. It will be interesting to see what happens when their Environmental Impact Report is published and the Michigan Department of Environmental Quality (MDEQ) holds the public 
hearings. It is intriguing to see the project go from exploration to development and possibly to an operating mine because that is such a rare occurrence in this particular industry.

One area that could be improved upon for the Eagle Project would be to hold more meetings than what is required for the permit application. It would also help to find a lasting positive economic benefit that could be put into the local community. The most important aspect of developing a mine in Marquette County is to make sure there will be no environmental damage because tourism is an important industry for Marquette County.

There are many opportunities for future work on sustainable development. Because it is such a new concept especially with regard to the mining industry some future work could be to analyze other mines after they have closed to see if they were sustainable. Another avenue for future work is to analyze a project in terms of sustainability before it even starts. Sustainability has such a general definition that it would be good to research what effect time has on sustainability. Is sustainability just a short term goal or is it too ideal to be determined in the long term.

Another issue is to apply sustainability to other industries with significant environmental and economic impacts, such as logging, agriculture or even major developments such as malls or subdivisions. It is naïve to assume that only mining could have such extensive economic and environmental impacts. All industries and/or business should be held to the same sustainability standard because they all impact greatly the local community that they are located in. 


\section{$\underline{\text { References }}$}

Anderson, B. (2000, 11 October). Sustainable Development-How Mining Plays a Role. Presented at Bureau of Land Management Symposium, Las Vegas. Retrieved July 31, 2005, from http://www.blm.gov/nhp/300/wo320/camma/bob.html.

Atkinson, G., Dubourge, R., Hamilton, K., Munasinghe, M., Pearce, D., Young, C. (1997). Measuring Sustainable Development Macroeconomics and the Environment. Lyme: Edward Elgar Publishing Limited.

Auty, R. M., Mikesell, R. F. (1998). Sustainable Development in Mineral Economies. Oxford: Clarendon Press.

Baker, S., Kousis, M., Richardson, D., Young, S. (Eds.). (1997). The Politics of Sustainable Development: Theory, Policy and Practice within the European Union. New York: Routledge.

Braga, T., Mikhailova, I. (2003). Local Sustainability Measurements and Determinants Investigating Industrial Stress, Economic Performance and Local Governance at Piraciabo Basin (Brazil). In Proceedings of the 2003 Berlin Conference on the Human Dimensions of Global Environmental Change (pp. 79-95). Berlin, Germany: Environmental Policy Research Centre.

Buege, D. J. (February 2004). The Crandon Mine Saga. Z Magazine Online, volume 17 (Number 2). Retrieved November 17, 2005, from http://zmagsite.zmag.org/Feb2004/ buegepr0204.html.

Crandon Mine Sold to Forest County Indian Tribes. (2003, October 28). Business Journal of Milwaukee. Retrieved November 17, 2005, from http://milwaukee.bizjournals.com/milwaukee/stories/2003/10/27/daily13.html.

Daly, H. (1990). Sustainable Development: From Concept and Theory to Operational Principles. Population and Development Review, 16, 25-43.

Daly, H. (1996). Beyond Growth; The Economies of Sustainable Development. Boston, MA.: Beacon Press Books.

Davis, G. (1998). The Minerals Sector, Sectoral Analysis, and Economic Development. Resources Policy, 24, 217-228.

Edelstein, D. L. (1994). Copper. United States Geological Survey Minerals Information-1994. Retrieved October 3, 2005, from http://minerals.usgs.gov/minerals/ Pubs/commodity/copper/240494.pdf. 
Edelstein, D. L. (1995). Copper. United States Geological Survey Minerals Information-1995. Retrieved October 3, 2005, from http://minerals.usgs.gov/minerals/ Pubs/commodity/copper/240495.pdf.

Edelstein, D. L. (1996). Copper. United States Geological Survey Mineral Commodity Summary-1996. Retrieved January 18, 2006, from http://minerals.usgs.gov/minerals/ Pubs/commodity/copper/coppemcs96.pdf.

Edelstein, D. L. (1996). Copper. United States Geological Survey Minerals Information-1996. Retrieved October 3, 2005, from http://minerals.usgs.gov/minerals/ Pubs/commodity/copper/240496.pdf.

Edelstein, D. L. (1997). Copper. United States Geological Survey Minerals Information-1997. Retrieved October 3, 2005, from http://minerals.usgs.gov/minerals/ Pubs/commodity/copper/240497.pdf.

Edelstein, D. L. (1997). Copper. United States Geological Survey Mineral Commodity Summary-1997. Retrieved January 18, 2006, from http://minerals.usgs.gov/minerals/ Pubs/commodity/copper/240397.pdf.

Edelstein, D. L. (1998). Copper. United States Geological Survey Mineral Commodity Summary-1998. Retrieved January 18, 2006, from http://minerals.usgs.gov/minerals/ Pubs/commodity/copper/240398.pdf.

Edelstein, D. L. (1999). Copper. United States Geological Survey Mineral Commodity Summary-1999. Retrieved January 18, 2006, from http://minerals.usgs.gov/minerals/ Pubs/commodity/copper/240399.pdf.

Edelstein, D. L. (2000). Copper. United States Geological Survey Mineral Commodity Summary-2000. Retrieved January 18, 2006, from http://minerals.usgs.gov/minerals/ Pubs/commodity/copper/240300.pdf.

Edelstein, D. L. (2001). Copper. United States Geological Survey Mineral Commodity Summary-2001. Retrieved January 18, 2006, from http://minerals.usgs.gov/minerals/ Pubs/commodity/copper/240301.pdf.

Edelstein, D. L. (2002). Copper. United States Geological Survey Mineral Commodity Summary-2002. Retrieved January 18, 2006, from http://minerals.usgs.gov/minerals/ Pubs/commodity/copper/240302.pdf.

Edelstein, D. L. (2003). Copper. United States Geological Survey Mineral Commodity Summary-2003. Retrieved January 18, 2006, from http://minerals.usgs.gov/minerals/ Pubs/commodity/copper/240303.pdf. 
Edelstein, D. L. (2004). Copper. United States Geological Survey Mineral Commodity Summary-2004. Retrieved January 18, 2006, from http://minerals.usgs.gov/minerals/ Pubs/commodity/copper/coppemcs04.pdf.

Edelstein, D. L. (2005). Copper. United States Geological Survey Mineral Commodity Summary-2005. Retrieved January 18, 2006, from http://minerals.usgs.gov/minerals/ Pubs/commodity/copper/coppemcs05.pdf.

Eggert, R. G. (October 2001). Mining and Economic Sustainability: National Economies and Local Communities. Mining, Minerals and Sustainable Development Project of International Institute for Environment and Development (no. 19). Retrieved from http://www.iied.org/mmsd/wp/index.html.

Environmental Protection Authority. (August 2004). Towards Sustainability. Position Statement Number 6. Australia.

Evans, T. J. (1996). Selected Developments in Wisconsin's Mineral Industry-1995. Wisconsin Geological and Natural History Survey-Educational Series 34. Retrieved November 17, 2005, from http://uwex.edu/wgnhs/pdfs/espdf/minsum95.pdf.

Evans, T. J. (1998). Selected Developments in Wisconsin's Mineral Industry in 1996 and 1997. Wisconsin Geological and Natural History Survey-Educational Series 34. Retrieved November 14, 2005, from http://uwex.edu/wgnhs/pdfs/espdf/es34-967.pdf.

Flambeau Mine website. Retrieved multiple times most recently on January 18, 2006, from http://www.flambeaumine.com

Foth and Van Dyke. (1989). Environmental Impact Report for the Kennecott Flambeau Project, Volume I-Report Narrative. Kennecott Minerals Company, Ladysmith WI.

Fox, F. D. (2003). Mining and Sustainable Development Flambeau and Ridgeway Mines-Lessons Learned. Paper Presented at Society for Mining, Metallurgy, and Exploration Annual Meeting (SME), Cincinnati, $\mathrm{OH}$.

Green, T. (2001). Evaluating Mining and its Effect on Sustainability: The Case of the Tulsequah Chief Mine. Prepared for Environmental Mining Council of British Columbia.

Grieg-Gran, M. (April 2002). Financial Incentives for Improved Sustainability Performance: The Business Case and the Sustainability Dividend. Mining, Minerals and Sustainable Development Project of International Institute for Environment and Development (no. 47). Retrieved from http://www.iied.org/mmsd/wp/index.html.

Humphreys, D. (2000, September). A Business Perspective on Community Relations in Mining. Resource Policy, 26(3), 127-131. 
Imrie, R. (2003, April 12). Company Buys Crandon Mine Site. Wausau Daily Herald. Retrieved November 14, 2005, from http://www.wausaudailyherald.com/wdhlocal/ 277457356138413.shtml.

International Institute for Environment and Development. (2002). Breaking New Ground: The Report of the MMSD Project. USA: Earthscan Publications. Retrieved From http://www.iied.org/mmsd/.

Keane, M. J. (2000, November). Wisconsin Briefs from the Legislative Reference Bureau. Retrieved November 17, 2005, from http://www.legis.state.wi.us/lrb/pubs/ wb/00wb15.pdf.

Kennecott Minerals Company. (1999). Social and Environmental Report 1999. Retrieved from http://www.kennecottminerals.com.

Kennecott Minerals Company. (2000). Social and Environmental Report 2000. Retrieved from http://www.kennecottminerals.com.

Kennecott Minerals Company. (2001). Social and Environmental Report 2001. Retrieved from http://www.kennecottminerals.com.

Kennecott Minerals Company. (2002). Social and Environmental Report 2002. Retrieved from http://www.kennecottminerals.com.

Kennecott Minerals Company. (2003). Social and Environmental Report 2003. Retrieved from http://www.kennecottminerals.com.

Kennecott Minerals Company. (2004). Social and Environmental Report 2004. Retrieved from http://www.kennecottminerals.com.

MacDonald, A. (2002). Mining, Minerals and Sustainable Development North America: Industry in Transition A Profile of the North America Mining Sector. Winnipeg, Manitoba: International Institute for Sustainable Development. Retrieved from http://www.iisd.org/natres/mining.

McMahon, G., Remy, F. (Eds.). (2001). Large Mines and The Community Socioeconomic and Environmental Effects in Latin America, Canada, and Spain. Washington D.C.: World Bank.

Mercando, L. E. (1991). Wetland Considerations for the Flambeau Mining Project Ladysmith, WI. [Preprint \#91-46 and Presentation for the SME Conference Denver February 25-28, 1991]. Littleton: SME.

Mineral Industry of Wisconsin. (1997). Retrieved November 17, 2005, from http://minerals.usgs.gov/minerals/pubs/state/985598.pdf. 
Mining Investment and Local Impact Fund Board 2001-2003 Biennial Report. Retrieved December 14, 2005, from http://www.dor.state.wi.us/ra/bie01-03.pdf.

Murphy, J. (2004, November). Kennecott Flambeau Mining Company Communities Relations Plan 2005-2009.

Northwest Regional Planning Commission (NWRPC). (2005, April). A Socioeconomic Study of the Flambeau Mine Project. Spooner: WI. Retrievable from http://www.flambeaumine.com.

Richards, J. P. (2002, January). Sustainable Development and the Minerals Industry. For publication in the Society of Economic Geologists Newsletter.

Rio Tinto Company’s webpage. Retrieved from http://www.riotinto.com

Rist, G. (1997). The History of Development: From Western Origins to Global Faith (P. Camiller, Trans.). New York: Zed Books.

Roe, L. A. (1991). A History of Wisconsin Mining. Madison, WI.: ROECO.

Society for Mining, Metallurgy, and Exploration. (1999, March 1). A Guide for Reporting Exploration Information, Mineral Resources, and Mineral Reserves. Littleton: SME.

Sosa, I. (2000, September). Mining and Communities: Literature Review and Annotated Bibliography. Prepared for Mining Watch Canada.

Stallworth, H. (1997). Economics of Sustainability. OSEC Issue Brief \#5 from the Office of Sustainable Ecosystems and Communities-U.S. Environmental Protection Agency.

Sustainable Development Webpages. Both retrieved on September 9, 2005, from http://www.natural-resources.org/minerals/cd/sustdev.html and http://www.un.org/esa/sustdev/csd/csd/-past.html.

Tahvonen, O. (2000, June). Economic Sustainability and Scarcity of Natural Resources A Brief Historical Review. Resources for the Future. Washington D.C.

Tisdell, C., \& Maitra, P. (Eds.). (1988). Technological Change, Development and the Environmental Socio-Economic Perspective. New York: Routledge.

Todd, J. W., Struhsacker, D. W. (1997). Environmentally Responsible Mining: Results Results and Thoughts Regarding a Survey of North American Metallic Mineral Mines. Retrieved November 17, 2005, from http://technology.infomine.com/enviromine/ publicat/enviroresponse.html. 
Torries, T. F. (1998). Evaluating Mineral Projects: Applications and Misconceptions. Littleton, CO.: SME.

United States Army Corps of Engineers. (2002, January). Crandon Mine Project Environmental Impact Statement Final Scoping Document. St. Paul, MN.

United States Bureau of Mines (USBM) and United States Geological Survey (USGS). (1980). Principles of a Resource/Reserves Classification for Minerals. Geological Survey Circular 831.

United States Environmental Protection Agency. Crandon Mine-Project Description and Project Summary. Retrieved November 17, 2005, from http://www.epa.gov/region5/ water/crandonmine/description.html.

United States Geological Survey. Copper Statistics and Information Page. Retrieved September 23, 2005, from http://minerals.usgs.gov/minerals/pubs/commodity/copper.

Veiga, M. M., Scoble, M., McAllister, M. L. (2001). Mining With Communities. Natural Resources Forum, 25, 191-202.

Walker, J., Howard, S. (2002). Finding the Way Forward: How Could Voluntary Action Move Mining Towards Sustainable Development?. London: Russell Press. Retrieved from http://www.iied.org/mmsd/library/follow-up.html.

Warhurst, A. (March 2002). Sustainability Indicators and Sustainability Performance Management. Mining, Minerals and Sustainable Development Project of International Institute for Environment and Development (no. 43). Retrieved from http://www.iied.org/mmsd/wp/index.html.

Wisconsin Department of Natural Resources (WDNR). (1990, March). Final Environmental Impact Statement Flambeau Mining Company-Copper Mine Ladysmith, WI. Madison, WI: WDNR.

Wisconsin Department of Natural Resources. (2003, May). Proposed Crandon MineProject Description. Retrieved November, 17, 2005, from http://dnr.wi.gov/org/es/science/crandon/project.html.

Wisconsin Department of Natural Resources. (2003, June). Information on the Reclaimed Flambeau Mine. Retrieved November 14, 2005, from http://dnr.wi.gov/ org/aw/wm/mining/metallic/flambeau/.

Wisconsin Department of Natural Resources. (2003, May). Overview of Permitting Process. Retrieved December 14, 2005, from http://www.dnr.state.wi.us/org/aw/wm/ mining/metallic/permitting-process/introduction.html. 
Wisconsin Department of Natural Resources. (2005). Nonmetallic Mining in Wisconsin. Retrieved December 14, 2005, from http://www.dnr.state.wi.us/org/aw/wm/mining/ nonmetallic/index.html.

Wisconsin Department of Natural Resources Mining Information Sheets. (2005a). The Permitting Process for a Metallic Mineral Mine. Retrieved November 17, 2005, from, http://dnr.wi.gov/org/aw/wm/mining/metallic/infosheets.html.

Wisconsin Department of Natural Resources Mining Information Sheets. (2005b). How the Department of Natural Resources Regulates Metallic Mining. Retrieved November 17, 2005, from, http://dnr.wi.gov/org/aw/wm/mining/metallic/infosheets.html.

Wisconsin Department of Natural Resources Mining Information Sheets. (2005c). Reclamation and Long-Term Care Requirements for Metallic Mining Sites in WI. Retrieved November 17, 2005, from, http://dnr.wi.gov/org/aw/wm/mining/metallic/infosheets.html.

Wisconsin Department of Natural Resources Mining Information Sheets. (2005d). Local Decisions in Metallic Mining Projects. Retrieved November 17, 2005, from, http://dnr.wi.gov/org/aw/wm/mining/metallic/infosheets.html.

Wisconsin Department of Natural Resources Mining Information Sheets. (2005e). Addressing Public Concerns with Wisconsin's Laws Governing Metallic Mining. Retrieved November 17, 2005, from, http://dnr.wi.gov/org/aw/wm/mining/metallic/infosheets.html.

Wisconsin Department of Natural Resources Mining Information Sheets. (2005f). Wisconsin's Net Proceeds Tax on Metallic Mining and Distribution of Funds to Municipalities. Retrieved November 17, 2005, from, http://dnr.wi.gov/org/aw/wm/mining/metallic/infosheets.html.

Wisconsin Department of Natural Resources Mining Information Sheets. (2005g). Cumulative Impacts of Metallic Mining Development in Northern Wisconsin. Retrieved November 17, 2005, from, http://dnr.wi.gov/org/aw/wm/mining/metallic/infosheets.html.

Wisconsin Department of Natural Resources Mining Information Sheets. (2005h). Potential Metallic Mining Development in Northern Wisconsin. Retrieved November 17, 2005, from, http://dnr.wi.gov/org/aw/wm/mining/metallic/infosheets.html.

Wisconsin Department of Natural Resources. (2005i). Proposed Crandon Mine Information. Retrieved November 17, 2005, from, http://dnr.wi.gov/org/es/science/crandon/. 
Wisconsin Department of Natural Resources. (2005j). 1997 Act 171: Mining Moratorium Law. Retrieved November 17, 2005, from,

http://dnr.wi.gov/es/science/crandon/review/moratorium.html. 


\section{APPENDIX A}


Major Provisions regarding the Local Agreement and Condition Land Use Permit

(from: NWRPC, 2005, p. 60-64)

- All necessary licenses and permits from the DNR shall be secured by the owners of the mine.

- The operation of the mine will comply with all DNR regulations applicable to the mine site and facilities. Copies of any documents applying for exemptions by Kennecott must be furnished to the local impact committee.

- The operator shall take preventative measures to minimize surface water runoff or erosion by finish grading and seeding completed areas of the mine according to an acceptable closing plan.

- The open pit shall be no greater than 40 acres and shall be excavated to a depth of no more than 225 feet below the existing grade.

- There will be no conversion from an open pit to deep shaft mineral mining.

- There shall be no smelting, concentrating or refining of ore on the mining company's land or in Rusk County.

- There will be no major expansion of the mine without reopening the Local Agreement and any land use permits granted.

- The mine area shall, at all times during the construction, operations, and closure phases of the project, be enclosed by a security fence with security gates of sufficient strength to control access to the mine.

- Flambeau Mining shall install, maintain, and utilize surface water containment systems and a mine water treatment facility to protect the groundwater and surface water of the county in accordance with certain specifications.

- All transportation of ore away from the site shall be via railroad. To achieve this, a rail spur to the main line shall be constructed at the mining company's expense. 
- Access to and from the mine will be limited to State Highway 27 via Blackberry Lane, unless a new access road is constructed entirely at the expense of the mine operator. The maximum number of access roads will be two unless a road is built from State Highway 27 to be used as access to a possible mine overlook.

- Certain limitations were stipulated regarding the location, height, and size of any buildings constructed on the active mine site. For each building constructed, sufficient off-street parking shall be provided for employee, agent, and guest automobiles and trucks.

- 300,000 tons of ore shall be the approximate projected amount of ore to be shipped from the mine each year.

- An area to allow visitors to park and observe the mining operation shall be provided.

- Blasting, crushing, and rail shipping shall be limited to daylight hours, Monday through Saturday only.

- Explosives will be a fertilizer base explosive consisting of ammonium nitrate and fuel-oil and/or dynamite. Any change to this form of explosive must be approved before use.

- The County Zoning Administrator shall have inspection powers and authority as outlined in the Permit for the purpose of determining compliance with the terms of the Permit.

- Mine trucks are to be confined to the mine site except in an emergency. In the event that trucks are used, certain restrictions are to be followed. Dust control from ore transportation, either by rail car or truck, must be in effect at all times.

- An average of 75 percent of all the mine workers shall be persons who have resided in or within 10 miles of the Rusk County border for a period of at least one year prior 
to hiring. This includes anyone hired directly by Flambeau Mining or by any contractor/subcontractor hired by Flambeau.

- Not less than six groundwater monitoring well clusters shall be constructed within the active mine area. These wells shall be tested on at least a quarterly basis and if water quality does not meet standards, certain defined procedures and measures shall be taken.

- Private off-site wells in a designated well guarantee area around the mine site will be tested, monitored, and guaranteed for 20 years after the mine ceases to operate.

- Property values in a designated area around the mine will be guaranteed for 20 years after the mine ceases to operate. Baseline property value appraisals will be paid for by the Flambeau Mining Company.

- A Local Mining Impact Committee shall be formed consisting of the chief elected official of the City, Town, and County or their designee (s) who possess no conflict of interest. This committee will monitor the ongoing status of the mining operation, hold public meetings, and report findings to the participating local units of government. Per Diem and travel expenses shall be paid by Flambeau Mining.

- Flambeau Mining Company will continue to run its water treatment facilities even if the mine closes temporarily.

- After completion of mining operations, the local units of government have the right of first refusal based on the highest bid received on any property (land, facilities, equipment) being sold by the Flambeau Mining Company.

- Upon conclusion of its mining phase, the mining company shall back fill the open pit according to a plan approved by the DNR.

- Prior to the construction phase of the mine operation, Flambeau will take an inventory of the existing vegetation. During the closure phase of the mine operation, Flambeau 
shall re-vegetate all disturbed sites in the active mine area. Flambeau will remain responsible for and insure viability of what it has planted for a period of 20 years.

- Prior to commencing mining operations, Flambeau will submit to the Local Impact Committee a copy of a closing plan for the mine.

- Flambeau agrees to lease to the participating local units of government, the following parcels for \$1.00: 1) A parcel on the north side of the former "Sisters' Farm" for use as a city outdoor recreation area and, 2) Flambeau River frontage adjacent to the end of Blackberry Lane for park purposes, which is the Town responsibility.

- Flambeau Mining will reimburse the participating local units of government for municipal costs and expenses incurred during negotiations up to the sum of $\$ 60,000$.

- For a period of 25 years, the mining company agrees to indemnify and hold harmless the participating local units of government from any or all liability as a result of claims, demands, costs, or judgments against them arising from the negotiation of this agreement. In addition, the mining company shall support, defend, and/or reimburse the participating local units of government for 75 percent of any legal expenses incurred with regard to the above mentioned actions.

- After the DNR issues the mining permit, but before mining begins, the mining company shall provide to the participating local units of government a certification that a bond payable to the DNR in the amount required under NR132 has been secured. The company must annually certify that it is in compliance with NR132 and it must maintain the bond for 30 years after closure of the mine.

- Under certain circumstances outlined in the Agreement, the participating local units of government or Kennecott may request that the Agreement be opened for renegotiation by serving a petition upon the other party.

- The Agreement is contingent upon the issuance of a conditional land use permit for the Mine. 
- A minimum of $\$ 1.5$ million (indexed for inflation) shall be paid in local taxes to the participating local units of government: Rusk County, the City of Ladysmith, and Town of Grant, regardless of copper price or profits. In 1993 dollars this amount is closer to $\$ 2.5$ million.

- The participating local units of government shall not oppose the development of the Mine or take any action to unreasonably delay or stop construction of the Mine.

- The provisions in the Agreement do not prohibit or restrict the participating local units of government from participating in the DNR permit hearing process.

The Local Agreement allowed for variances in the language of the Agreement, but those variances can only address the operation of the mine and/or the language of the Agreement. All such changes must be agreed to by all parties to the Agreement. 


\section{APPENDIX B}




\section{Flambeau Mine Socioeconomic Survey for both Business and Residents}

(from: NWRPC, 2005)

\section{Flambeau Mine Socio-Economic Study}

A socio-economic study is currently being developed to gauge the impact of the Flambeau Mine on local governments and residents of Rusk County. Please complete the following questions and return the survey in the postage-paid envelope. Northwest Regional Planning Commission, located in Spooner, is preparing the study. Thank you for your participation.

A total of $\underline{419}$ responses were received. Not all questions were answered by every respondent.

1. Did you live in Rusk County during the operation of the Flambeau Mine? 352 Yes 53 No

2. Do you live in the City of Ladysmith or the Town of Grant? 349 Yes 65 No

If yes, how long have you lived in Ladysmith? From 1 to 88 years

3. How would you rate Flambeau Mining Company as a corporate citizen providing long-term benefits to the local community?
140 Excellent
$141 \mathrm{Good}$
53 Fair
52 Poor

(check only one)

\begin{tabular}{|c|c|c|c|c|}
\hline $\begin{array}{l}\text { Strongly } \\
\text { Agree }\end{array}$ & $\begin{array}{l}\text { Somewhat } \\
\text { Agree }\end{array}$ & $\begin{array}{l}\text { Somewhat } \\
\text { Disagree }\end{array}$ & $\begin{array}{l}\text { Strongly } \\
\text { Disagree }\end{array}$ & $\begin{array}{l}\text { Don't } \\
\text { Know }\end{array}$ \\
\hline 143 & 146 & 31 & 54 & 35 \\
\hline 202 & 128 & 15 & 28 & 35 \\
\hline 134 & 103 & 48 & 59 & 62 \\
\hline 121 & 120 & 59 & 65 & 44 \\
\hline 134 & 128 & 49 & 64 & 34 \\
\hline 160 & 135 & 40 & 37 & 38 \\
\hline 124 & 121 & 56 & 65 & 44 \\
\hline 105 & 110 & 47 & 53 & 91 \\
\hline
\end{tabular}

11. The Flambeau Mining Company effectively engaged stakeholders and the local governments to allow communities to participate in the decision-making process. 
12. Were you concerned about the impact to the environment prior to or during mine construction?
270 Yes
132 No

If yes, did the mining company adequately address your concerns?

194 Yes $\quad 75$ No

13. Flambeau Mining Company made certain promises to the people of Rusk County to protect the environment, provide economic benefits (jobs and tax revenue) and reclaim the mine site. Did the Flambeau Mining Company keep their promise to:

$\begin{array}{lll}\text { Protect the Environment } & 330 \text { Yes } & 42 \text { No } \\ \text { Provide Economic Benefits } & 289 \text { Yes } & 85 \text { No } \\ \text { Reclaim the Mine Site } & 356 \text { Yes } & 27 \text { No }\end{array}$

14. If another ore deposit were found in the vicinity of your community, would you welcome Flambeau Mining Company back to mine it?

285 Yes 94 No

15. How much in total do you think local governments (Town of Grant, City of Ladysmith, and Rusk County) received in mining taxes and proceeds from the Flambeau Mining Company while in operation?

20 Less than $\$ 100,000$

$42 \$ 100,000-\$ 499,000$

$47 \$ 500,000-\$ 999,999$

$81 \$ 1,000,000-\$ 4,999,999$

$30 \$ 5,000,000-\$ 9,999,999$

$25 \$ 10,000,000-\$ 14,999,999$

$13 \$ 15,000,000-\$ 20,000,000$

15 more than $\$ 20,000,000$ 
16. Have you used the recreational trails constructed on the reclaimed site of the Flambeau Mine?

127 Yes 281 No

17. What is your gender: 239 Female 167 Male

18. What is your age: 1 Under 20 $56 \quad 35-44$ $78 \quad 65-74$

$120-24$ $106 \quad 45-54$

6375 and older
$8 \quad 25-34$

$93 \quad 55-64$

19. How many persons reside in your household? $77 \quad 1$ person

1972 persons

493 persons

364 persons

245 persons

76 persons

27 persons

28 or more persons 


\section{Flambeau Mine Socio-Economic Study \\ Business and Commerce Survey}

A socio-economic study is currently being developed to gauge the impact of the Flambeau Mining operations on local governments and residents of Rusk County. As part of this study, a survey of local businesses is being conducted to determine whether the mining operations had any impact on local businesses. Please complete the following questions and return the survey in the postage-paid envelope. Northwest Regional Planning Commission, located in Spooner, is preparing the socio-economic study. Thank you for your participation.

A total of $\underline{95}$ responses were received. Not all questions were answered by every respondent.

1. Was your business in existence during the operation of the Flambeau Mine between 1991 and 1998 ?

80 Yes $\quad 12$ No

If no, please skip questions 2-7 and go to question 8 .

2. Were you expecting to get any business from the operations at the Flambeau Mine?

35 Yes $\quad 43$ No

3. Did the Flambeau Mining Company or its contractors or subcontractors purchase goods and materials from your business?

35 Yes $\quad 44$ No

4. Overall, did the presence of the Flambeau Mine benefit your business?

10 Significantly 42 Somewhat $\quad 24$ Not at All 4 Don't Know

5. Did your business hire additional employees as a direct result of the presence of the Flambeau Mine?

5 Yes $\quad 75$ No 
6. Since the Flambeau Mine Company completed its reclamation project (1998), has your company had to permanently reduce its employee size?

7 Yes $\quad 70$ No

If yes, was it the result of the following? (check all that apply)

2 Flambeau Mine ceasing operations

2 September 2002 tornado

1 Regional or National economics

4 Other

7. Approximately how many full-time equivalent employees (including yourself) did your business have in November 1997 ?
$42 \quad 1-5 \quad 11 \quad 6-10$
$711-15$
$316-20$
1521 or more

8. Approximately how many full-time equivalent employees (including yourself) do you have in November 2004?
$\begin{array}{llll}49 & 1-5 \quad 17 & 6-10\end{array}$
4 11-15
$5 \quad 16-20$
1421 or more

9. What type of business do you own or manage?

10. Optional: What is the name of your business? 